\title{
OPEN Dissecting fine-flavor
} cocoa bean fermentation through metabolomics analysis to break down the current metabolic paradigm

Fabio Herrera-Rocha ${ }^{1,5}$, Mónica P. Cala ${ }^{2,5}$, Jenny Lorena Aguirre Mejía ${ }^{3}$, Claudia M. Rodríguez-López ${ }^{3}$, María José Chica ${ }^{3}$, Héctor Hugo Olarte ${ }^{3}$, Miguel Fernández-Niño ${ }^{1,4 \bowtie}$ \& Andrés Fernando Gonzalez Barrios ${ }^{1 \bowtie}$

Cocoa fermentation plays a crucial role in producing flavor and bioactive compounds of high demand for food and nutraceutical industries. Such fermentations are frequently described as a succession of three main groups of microorganisms (i.e., yeast, lactic acid, and acetic acid bacteria), each producing a relevant metabolite (i.e., ethanol, lactic acid, and acetic acid). Nevertheless, this view of fermentation overlooks two critical observations: the role of minor groups of microorganisms to produce valuable compounds and the influence of environmental factors (other than oxygen availability) on their biosynthesis. Dissecting the metabolome during spontaneous cocoa fermentation is a current challenge for the rational design of controlled fermentations. This study evaluates variations in the metabolic fingerprint during spontaneous fermentation of fine flavor cocoa through a multiplatform metabolomics approach. Our data suggested the presence of two phases of differential metabolic activity that correlate with the observed variations on temperature over fermentations: an exothermic and an isothermic phase. We observed a continuous increase in temperature from day 0 to day 4 of fermentation and a significant variation in flavonoids and peptides between phases. While the second phase, from day four on, was characterized for lower metabolic activity, concomitant with small upward and downward fluctuations in temperature. Our work is the first to reveal two phases of metabolic activity concomitant with two temperature phases during spontaneous cocoa fermentation. Here, we proposed a new paradigm of cocoa fermentation that considers the changes in the global metabolic activity over fermentation, thus changing the current paradigm based only on three main groups of microorganism and their primary metabolic products.

Cocoa fermentation is an essential step in chocolate production ${ }^{1,2}$. This process is critical for the biosynthesis of relevant flavors and bioactive compounds that determine the chocolate quality ${ }^{2-4}$. Incomplete/shorter fermentations result in cocoa with undesirable astringent flavors ${ }^{3}$, while overfermentations result in undesirable hammy and putrid flavors ${ }^{5,6}$. Despite their high relevance, very little information is available regarding the biochemistry and microbiology of cocoa fermentation. Additional research is still required to elucidate the synthesis of valuable compounds during this critical step in chocolate production.

Cocoa fermentation is a highly complex spontaneous process led by the interaction of heterogeneous microbial populations. Even though it is generally accepted that the origin of this microbial community is the environment(e.g., insects, worker hands, tools, and air) the exact origin of every microorganism group present in the coco fermentation has not been proven so $\mathrm{far}^{3,7}$. For this reason, the origin of the microbial community

\footnotetext{
${ }^{1}$ Grupo de Diseño de Productos Y Procesos (GDPP), Departamento de Ingeniería Química Y de Alimentos, Universidad de los Andes, 111711 Bogotá, Colombia. ${ }^{2}$ MetCore - Metabolomics Core Facility. Vice-Presidency for Research, Universidad de los Andes, Bogotá, Colombia. ${ }^{3}$ CasaLuker S.A., Bogotá, Colombia. ${ }^{4}$ Department of Bioorganic Chemistry, Leibniz-Institute of Plant Biochemistry, Weinberg 3, 06120 Halle, Germany. ${ }^{5}$ These authors contributed equally: Fabio Herrera-Rocha and Mónica P. Cala. ${ }^{\varpi}$ email: mfernand@ipb-halle.de; andgonza@ uniandes.edu.co
} 
accountable for cocoa fermentation is still unclear ${ }^{3,8,9}$. Three significant phases during spontaneous cocoa fermentations have been previously proposed ${ }^{10-13}$ due to the interactions between three main groups of microorganisms (yeast, lactic acid bacteria, and acetic acid bacteria) and their metabolic products ${ }^{9,14}$. An initial anaerobic phase occurs at the beginning of the fermentation, in which yeasts produce ethanol using the fermentable sugars from the cocoa pulp 9 . Then, when the pulp begins to disappear and oxygen penetrates at a higher rate the fermentation mass, a second (aerobic) phase occurs. In this phase, Lactic Acid Bacteria (LAB) utilizes the remaining sugars (mainly fructose) to produce lactic acid that accumulates 9,15 . Finally, the last phase occurs when acetic acid bacteria $(\mathrm{AAB})$ convert ethanol into acetic acid that strongly affects the microbial diversity of fermentation ${ }^{9,15,16}$. Based on this paradigm, different mathematical models of cocoa fermentation have been previously proposed to further study the dynamics among these phases ${ }^{10-13}$. Apart from the general metabolic activity, other specific biochemical processes in cocoa fermentation have been modeled. For instance, genome-scale reconstructions for selected strains of acetic acid and lactic acid bacteria isolated from cocoa fermentations have been proposed in various studies, even using advanced techniques as fluxomic to improve the models ${ }^{17-19}$.

However, recent metagenomics studies highlighted the relevance of other dominant groups of microorganisms during cocoa fermentations $s^{8,13,14,20-23}$. The results of these studies question the traditional view of cocoa fermentation. For instance, the dominance of other microorganisms such as Bacillus, Pseudomonas, Aspergillus, Malasse$z i a$, and Pestalotiopsis at several phases during cocoa fermentations have been recently demostrated ${ }^{8,13,14,20-23}$. The role of these microorganisms and their potential to produce valuable flavor and bioactive compounds during spontaneous cocoa fermentation still have to be elucidated. Therefore, a current essential challenge in cocoa research is identifying metabolites associated with these microorganisms to better understand their relevance during cocoa fermentation. However, only a few studies have dissected the variation in the metabolic profile during spontaneous cocoa fermentation $\mathrm{s}^{24-28}$. Most of these studies focus on identifying metabolites during the fermentation of bulk cocoa (i.e., cocoa varieties with an ordinary flavor profile). In contrast, these kinds of analyses are rare and still in their infancy for fine-flavor cocoa. In this regard, to understand the metabolic dynamic of fine-flavor cocoa fermentation is a necessary previous step to connect the metabolites and microorganisms involved in this process.

Compared to bulk cocoa, fine-flavor offers a higher diversity of flavor attributes of high demand by the elite chocolatiers. Therefore, identifying changes in the metabolic fingerprint during spontaneous fermentation of fine-flavor cocoa is highly relevant to standardize this process and produce a high-quality bar of chocolate. Consequently, the goal of this study was to analyze the changes in the metabolic fingerprint during spontaneous fermentation of fine-flavor cocoa. Our data revealed two main phases of differential metabolic activity during spontaneous fermentation of fine-flavor cocoa that correlated with the observed variations on temperature and highlighted the relevance of comprehensive metabolomics studies to break down the current cocoa fermentation paradigm.

\section{Experimental section}

Cocoa beans fermentation. Cocoa fermentations were performed at the Luker Farm (Caldas, Colombia $\left(5^{\circ} 4^{\prime} \mathrm{N} 75^{\circ} 41^{\prime} \mathrm{W}\right)$ ) owned by CasaLuker S.A. Cocoa beans, from a standard, pre-designed, and a frequently-used mixture of Theobroma cacao clones (i.e., LUKER40, FSV41, FSA13, and TSH565), were selected for wooden box fermentations. Additional information regarding the used clones is available at the International Cocoa Germplasm Database (ICGD) (http://www.icgd.reading.ac.uk/).

Two independent fermentation boxes containing $400 \mathrm{~kg}$ of cocoa pulp-bean mass each was arranged using a ladder system in a pre-designed fermentation room as previously described ${ }^{13}$. Briefly, this fermentation room has an area of $84 \mathrm{~m}^{2}$ with a metallic ceiling and acrylic walls to prevent air current entering the fermentation zone. The average temperature and during day time are $33^{\circ} \mathrm{C}$ while at night time is $25^{\circ} \mathrm{C}$. Humidity is around $60 \%$ with a maximum level of $94 \%$. The fermentation mass was mixed from the fourth day on, every $48 \mathrm{~h}$,to allow aeration. Standard cutting tests were used to evaluate the fermentation quality over time and determine its final point following the standard protocols ${ }^{13}$.

Fermentation mass sampling. Three biological replicates, each consisting of 10 seeds, were collected from different fermentation mass locations-two of them from one fermentation box and the third one from the other fermentation box, as previously described ${ }^{13}$. Sampling was made at the beginning and every $24 \mathrm{~h}$ until the end of fermentation. To avoid chemical degradation, samples were frozen immediately at $-80{ }^{\circ} \mathrm{C}$ after collection. Furthermore, to connect the medium conditions and metabolic activity, we recorded the fermentation cocoa mass temperature variation every $4 \mathrm{~min}$ for each fermentation box using precision sensors placed in the center of the fermentation boxes.

This sampling process followed the guidelines and legislation settled by the ministry of environment and sustainable development of Colombia. We obtained a permission to access genetic and derivate resources according to resolution No 284 of 2020.

Sample preparation. Fermentation samples were initially milled using a clean and precooled coffee grinder. Aliquots of $100 \mathrm{mg}$ were further macerated in the presence of liquid nitrogen and subsequently defatted by the addition of $500 \mu \mathrm{L}$ of $\mathrm{n}$-hexane and vigorous vortex as previously reported ${ }^{29}$. Defatting was repeated three times for each sample to maximize the lipid removal. Metabolite extraction was performed by adding $1 \mathrm{~mL}$ of methanol-ultrapure water (70:30) to each sample. Then these extracts were placed into an ultrasonic bath at room temperature for $10 \mathrm{~min}$ following by vortex-mixed for $10 \mathrm{~min}$. After that, the samples were centrifuged at $6000 \mathrm{~g}, 25^{\circ} \mathrm{C}$ for $10 \mathrm{~min}$, and the supernatant was collected for LC-QTOF-MS and GC-QTOF-MS analysis. For LC-QTOF-MS analysis, $30 \mu \mathrm{L}$ of supernatant was mixed with $70 \mu \mathrm{L}$ of Milli Q water and transferred to LC-MS 
vials. For GC-QTOF-MS, $30 \mu \mathrm{L}$ of supernatant was evaporated to dryness using a SpeedVac concentrator system. Methoxymation was performed by adding $20 \mu \mathrm{L}$ of $O$-methoxyamine hydrochloride $(30 \mathrm{mg} / \mathrm{mL}$ in pyridine) to each sample and vigorously vortex-mixed $5 \mathrm{~min}$. Then, samples were incubated at $70{ }^{\circ} \mathrm{C}$ for $1 \mathrm{~h}$. Then, $20 \mu \mathrm{L}$ of BSTFA with $1 \%$ of TMCS were added, vortex-mixed for $5 \mathrm{~min}$, and placed in the oven at $70^{\circ} \mathrm{C}$ for $1 \mathrm{~h}$. Finally, $100 \mu \mathrm{L}$ of heptane containing C18:0 methyl ester $(5 \mu \mathrm{g} / \mathrm{mL})$ as internal standard.

Metabolic fingerprinting by LC- QTOF-MS analysis. The metabolic analysis was performed using an Agilent 1260 Infinity LC System coupled with Q-TOF 6545 MS system (Agilent Technologies, Palo Alto, CA, USA). $5 \mu \mathrm{L}$ of the extracted sample was injected onto InfinityLab Poroshell 120 EC-C18 column $(2.1 \times 150 \mathrm{~mm}$ $2.7 \mu \mathrm{m}$, Agilent) thermostated at $30^{\circ} \mathrm{C}$. The flow rate of mobile phase (A: Milli-Q water with $0.1 \%$ formic acid $(\mathrm{v} / \mathrm{v})$, B: acetonitrile with $0.1 \%$ formic acid $(\mathrm{v} / \mathrm{v}))$ was $0.4 \mathrm{~mL} / \mathrm{min}$. The gradient elution program started running at $5 \% \mathrm{~B}$, increasing to $10 \% \mathrm{~B}$ in $7 \mathrm{~min}$, then increasing to $95 \% \mathrm{~B}$ in $15 \mathrm{~min}$ and hold at $95 \% \mathrm{~B}$ for $2 \mathrm{~min}$, ending going back to initials conditions in $1 \mathrm{~min}$ and held there for $8 \mathrm{~min}$ to allowed column re-equilibrium. The analysis was performed with positive and negative ionization mode using two reference masses in each polarity: $m / z 121.0509\left(\mathrm{C}_{5} \mathrm{H}_{4} \mathrm{~N}_{4}\right)$ and $m / z 922.0098\left(\mathrm{C}_{18} \mathrm{H}_{18} \mathrm{O}_{6} \mathrm{~N}_{3} \mathrm{P}_{3} \mathrm{~F}_{24}\right)$ in positive mode an $m / z 112.9856\left(\mathrm{C}_{2} \mathrm{O}_{2} \mathrm{~F}_{3}\left(\mathrm{NH}_{4}\right)\right)$ and $m / z 1033.9881\left(\mathrm{C}_{18} \mathrm{H}_{18} \mathrm{O}_{6} \mathrm{~N}_{3} \mathrm{P}_{3} \mathrm{~F}_{24}\right)$ for negative ionization mode. The system was operated in full scan mode from 100 to $1100 \mathrm{~m} / z$. The capillary voltage was set to 3500 ; the drying gas flow rate was $8 \mathrm{~L} / \mathrm{min}$ at $325^{\circ} \mathrm{C}$, gas nebulizer 50 psi, fragmentation voltage $175 \mathrm{~V}$ and skimmer $65 \mathrm{~V}$ and octopole radio frequency voltage (OCT RF Vpp) $750 \mathrm{~V}$. Data were collected in the centroid mode at a scan rate of 1.00 spectrum per second.

Metabolic fingerprinting by GC-QTOF-MS analysis. Metabolic fingerprinting was performed using an Agilent Technologies 7250 GC/QTOF system (Agilent Technologies, Palo Alto, CA, USA). $2 \mu \mathrm{L}$ of the derivatized sample was injected onto an HP-5MS UI column $(30 \mathrm{~m} \times 0.25 \mathrm{~mm} \times 0.25 \mu \mathrm{m})$, using helium as a carrier gas at a constant gas flow of $0,7 \mathrm{~mL} / \mathrm{min}$. Injector temperature was set at $280{ }^{\circ} \mathrm{C}$ and split ratio to $30: 1$. The gradient temperature program started at $60^{\circ} \mathrm{C}$, held there for $1 \mathrm{~min}$, and then started to increase to $325^{\circ} \mathrm{C}$ with a rate of $10^{\circ} \mathrm{C} / \mathrm{min}$. The GC-MS transfer line was set at 280 , filament source at 250 , and quadrupole temperature at 150 . The electron ionization (EI) source was set at $70 \mathrm{eV}$, and the mass spectrometer was operated in full scan mode from 50 to $600 \mathrm{~m} / z$ at a scan rate of 5.00 scans/s.

Quality control samples. Quality control (QC) samples were prepared by mixing equal volumes of extracted samples. To determine the reproducibility and stability of the analytical platforms used, several QC runs were performed before analyzing all cocoa samples until system equilibration was achieved and every five randomized samples.

Data treatment. All raw data were processed as previously reported by Cala et $\mathrm{al}^{30}$. In summary, for LCQTOF-MS data processing was performed withAgilent MassHunter Profinder B.10.0 Software for deconvolution, alignment, and integration.. GC-MS data processing consisted of a deconvolution step with Agilent MassHunter Unknowns Analysis B.10.00 and metabolite identification using the libraries Fiehn version 2015 and NIST 17. Agilent Mass Profiler Professional B.12.1 software was used for retention time alignment, and then withAgilent MassHunter Quantitative B.10.00 was performed the integration of each metabolite following Agilent guidelines. Both LC-MS and GC-MS data were inspected manually to clean thenoise. Finally, data were filter by presence and reproducibility, maintaining the metabolites present in $100 \%$ of the biological replicates in each group and a coefficient of variation in the QC lower than $20 \%$.

Statistical analysis. To determine statistically significant differences between metabolomics profiles, multivariate (MVA) statistical analyses were performed using SIMCA 16.0 (Umetrics, Umea, Sweden). Principal component analysis (PCA) was applied to evaluate the acquired data quality, verifying that the QC samples were correctly clustered in these models to guarantee the stability of the analytical system. After that, PLSDA and OPLS-DA models were built to maximize and inspect the differences between study groups and select responsible metabolites for separating the groups. Pareto scaling were used before the statistical analysis. For all platform data, the significant variables were selected by keeping only the variables that fulfilled:1) MVA criteria (variance significant in projection (VIP) $>1.5$ with Jack-knife confident interval (JK) not including the zero value from orthogonal partial least-squares discriminant analysis (OPLS-DA) with CV-ANOVA $<0.05)$ and 2 ) Change percent $>30 \%$.

Metabolites identification. Accurate masses of features representing significant differences in class separation identified by all platforms were searched in the following databases: KEGG (http:// genome.jp/keg) and Lipid MAPS (http://lipidmaps.org), METLIN (http://metlin.scripps.edu) using the CEU Mass Mediator tool ${ }^{31}$. Then LC-MS/MS analyses were performed to confirm the metabolite's identity.

\section{Results and discussion}

A Multiplatform metabolic fingerprinting of fine-flavor cocoa fermentation was obtained through LC-OTOF-MS and GC-OTOF-MS. We used LC-QTOF-MS and GC-QTOF-MS to elucidate the metabolic activity through the cocoa fermentation process. The total coverage of molecular features from the metabolic fingerprinting (MF) after data processing and filtering that we obtained consisted of 1497, 551, and 71 features by LC-QTOF-MS(+), LC-QTOF-MS(-), GM-and GC-QTOF-MS(+), respectively. Using quality control (QC) samples clustering, we evaluated the performance of the different analytical platforms in unsupervised 

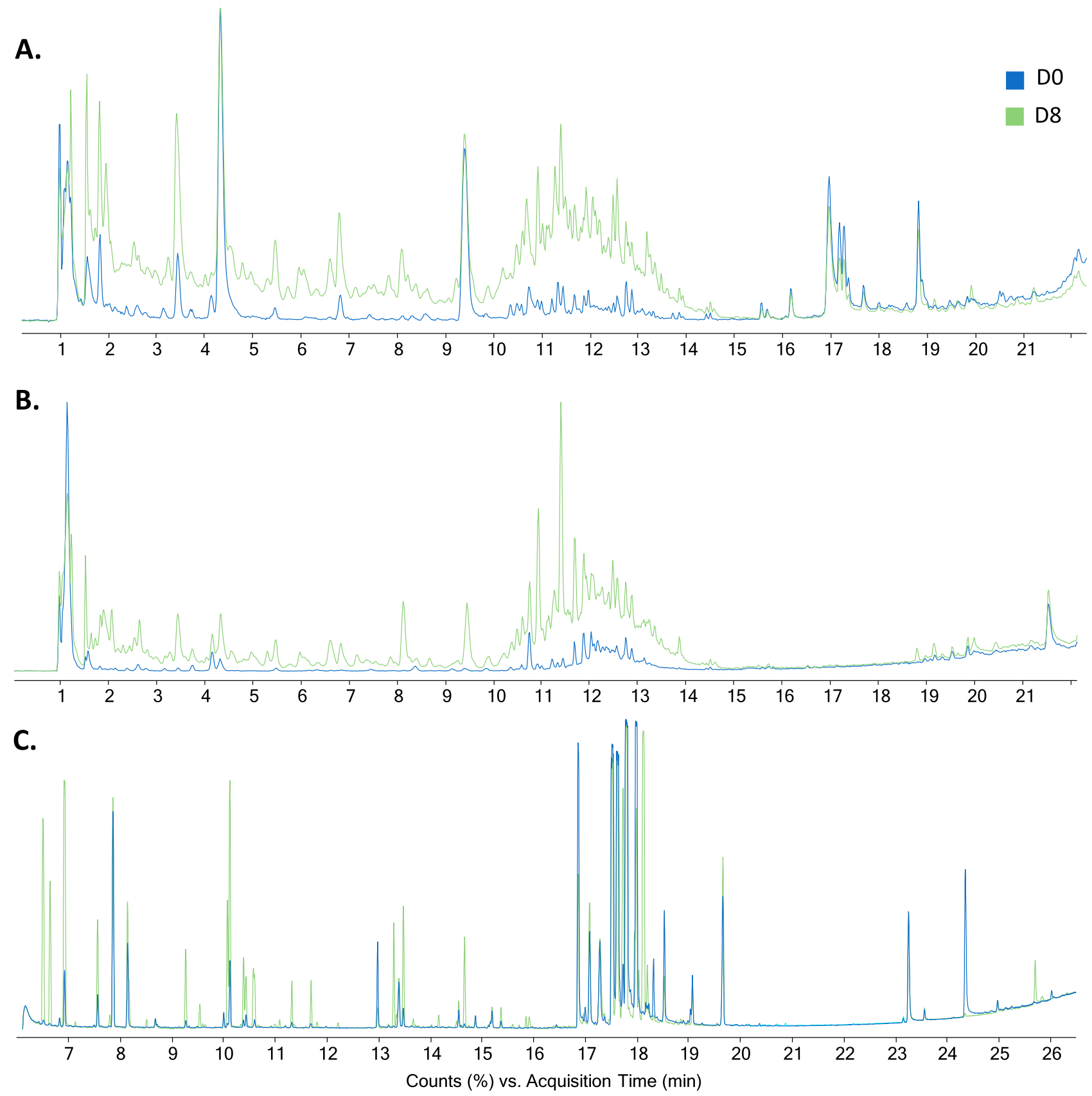

Figure 1. Comparison of total ion chromatogram of metabolic profiles for day 0 (D0) and day 8 (D8) during fermentation of fine-flavor cocoa. (A) Metabolic fingerprinting (MF) by LC-MS(+); (B) MF by LC-MS(-); (C) MF by GC-MS.

PCA models (Supplementary Fig. S1). A clear QC grouping was observed in PCA analysis for all analytical platforms, assuring the quality of acquired data and supporting that separating groups is related to biological and not analytical variations. Overall, we observed a significant difference between the metabolic fingerprint of the beginning (day 0 ) and the end (day 8 ) of the fermentation (Fig. 1), generally characterized by an increase in the signals of fermentation day 8 . For all platforms, the PCA analysis revealed a clear separation between the metabolic fingerprint of day 0 and day 8 of the fermentation and a change in metabolite throughout all fermentation days (Fig. 2). However, the analysis of the metabolic fingerprint for each day revealed only a slight separation between specific days such as day 0 and day 1, day 2 and day 3, and the last three days of fermentation (i.e., day 6 , day 7, and day 8), suggesting that these days exhibit a similar metabolic profile. This same behavior has been previously reported in several studies ${ }^{24,25,28}$.

Two different phases of metabolic activity were detected during spontaneous fermentation of fine-flavor cocoa beans. PLS-DA models were built to explore and maximize the differences in metabolic 

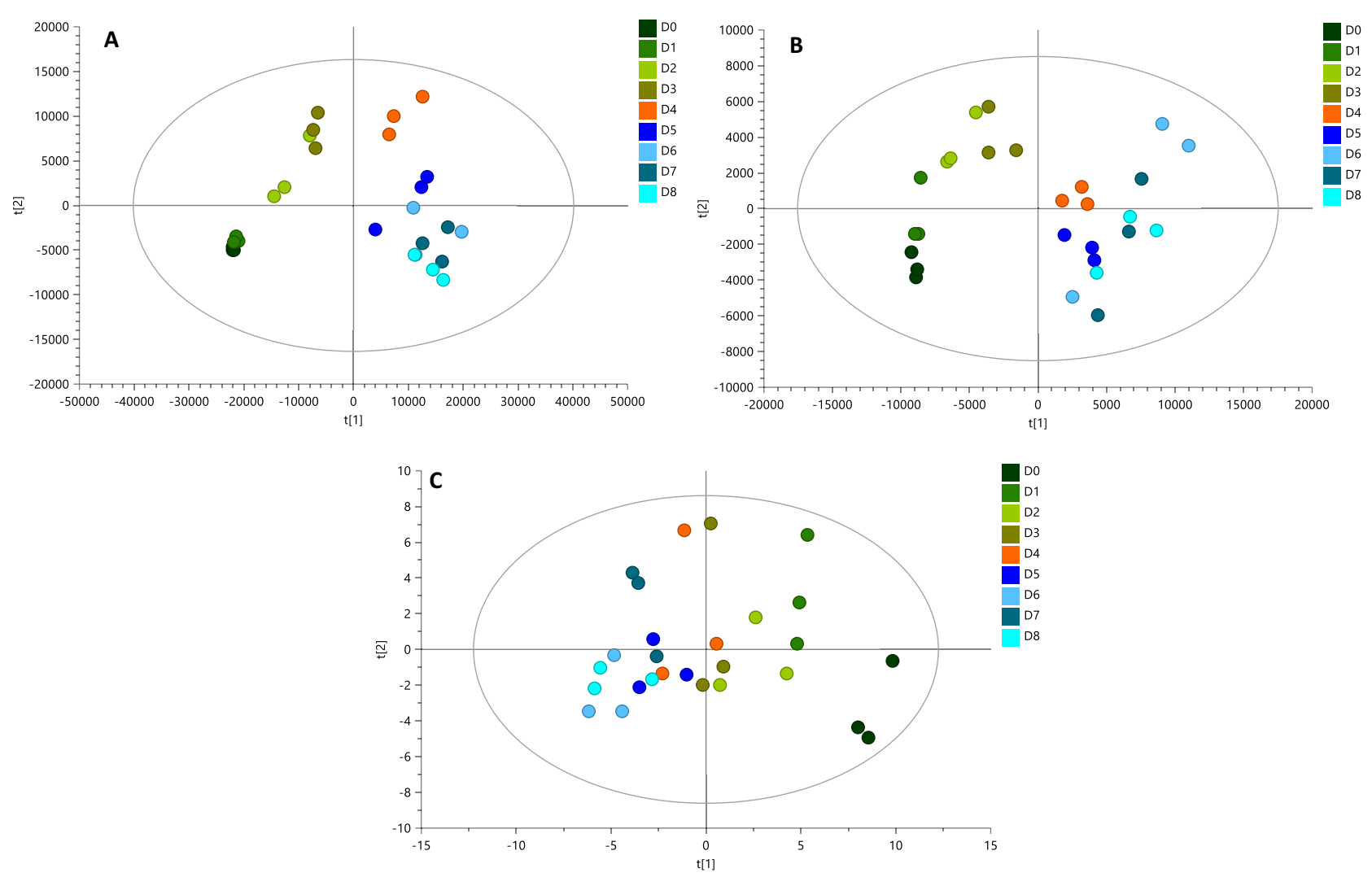

Figure 2. PCA score plots for all fermentation samples. (A) MF by LC-MS(+): $\mathrm{R}^{2}$ (cum): $0.875, \mathrm{Q}^{2}$ (cum): 0.826; (B) MF by LC-MS(-): $\mathrm{R}^{2}$ (cum): 0.876, $\mathrm{Q}^{2}$ (cum): 0.77; (C) MF by GC-MS: $\mathrm{R}^{2}$ (cum): $0.724, \mathrm{Q}^{2}$ (cum): 0.229 .

fingerprint throughout the fermentation process (Fig. 3A-C). The PLS-DA models showed little discrimination in the metabolic fingerprint of the fermentation process on each day in all analytical platforms; however, in the PLS-DA score plots, it is possible to observe three clusters of fermentation days corresponding to D0-D3, D4, and D5-D8. Using this approach, additional PLS-DA models were built to explore the differences between these three groups (Fig. 3D-F). A clear separation was observed in the score plots for all PLS-DA models between these groups with high quality, proven by significant variance values explained $\left(\mathrm{R}^{2}\right)$, variance predicted $\left(\mathrm{Q}^{2}\right)$, and CV-ANOVA. These results suggest that the most prominent metabolites changes cluster in two phases (D0 to D3 and D5 to D8) during the fermentation process of cocoa beans. To further explore the trends in metabolites modifications along fermentation days, a heatmap was built for all metabolite features detected in all analytical platforms using MetaboAnalyst 5.0 (Fig. 4). The groups (days) in the diagram were allocated using a hierarchical clustering algorithm, joining them by similarity, as indicates the dendrogram on the top of the figure. This heatmap shows two similar metabolic fingerprint with differential alteration of a significant number of metabolites between them. The first metabolic fingerprint goes from day 0 to day 3 and the second one from day fifth on, supporting the presence of two major metabolic phases during the fermentation of fine-flavor cocoa. Interestingly, these two phases are concomitant with the temperature profile in the cocoa mass through the entire process (Fig. 5).

The temperature of the fermenting mass is a crucial parameter during spontaneous fermentation of fine-flavor cocoa. Our data revealed two different temperature phases during spontaneous cocoa fermentation (Fig. 5) concomitant to the two phases of differential metabolic activity previously described (Figs. 3 and 4). The first phase is essentially exothermic. During this phase, the temperature of the fermenting mass significantly increased from $26.8 \pm 0.3^{\circ} \mathrm{C}$ to $49.4 \pm 2.5^{\circ} \mathrm{C}$. Contrary, the second phase (from the fifth day on) is primarily isothermic. The temperature during second phase remained between 45 and $50{ }^{\circ} \mathrm{C}$ until the fermentation ended, a variation $81 \%$ lower compared with the exothermic phase. This kind of temperature profile was reported in different cocoa fermentations worldwide, with different cocoa varieties, fermentation methods, and weather conditions ${ }^{20,21,32,33}$.

Temperature rise, usually more than $25^{\circ} \mathrm{C}$ over the initial temperature of cocoa mass, could be associated with exothermic reactions (e.g., ethanol and weak acids production) from the first days of fermentation ${ }^{10,34,35}$. A maximum temperature increase rate was observed on fermentation day 4 , which corresponds with the first turning of the fermenting mass to allow oxygenation. Thus, oxygen availably could partially explain the increase in temperature as a substantial increase in oxygen concentration may lead to a dramatic rise in exothermic oxidation 


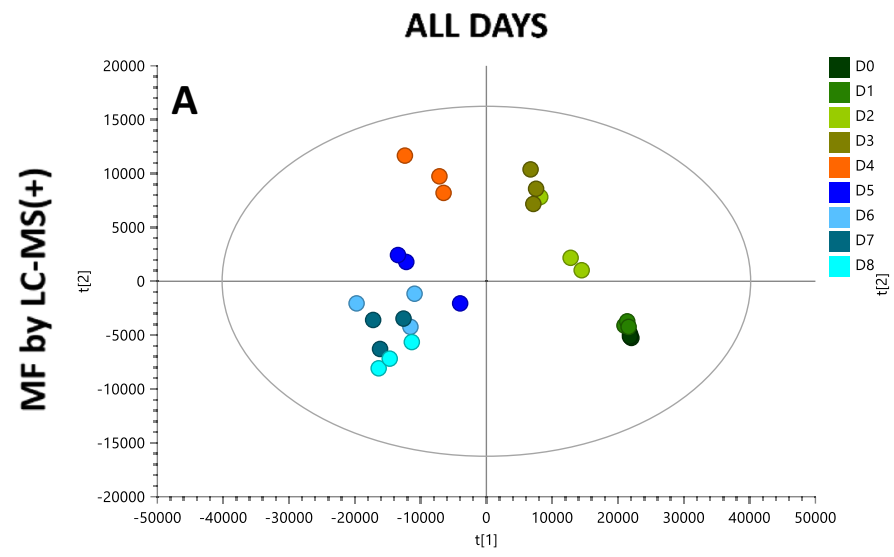

PHASES
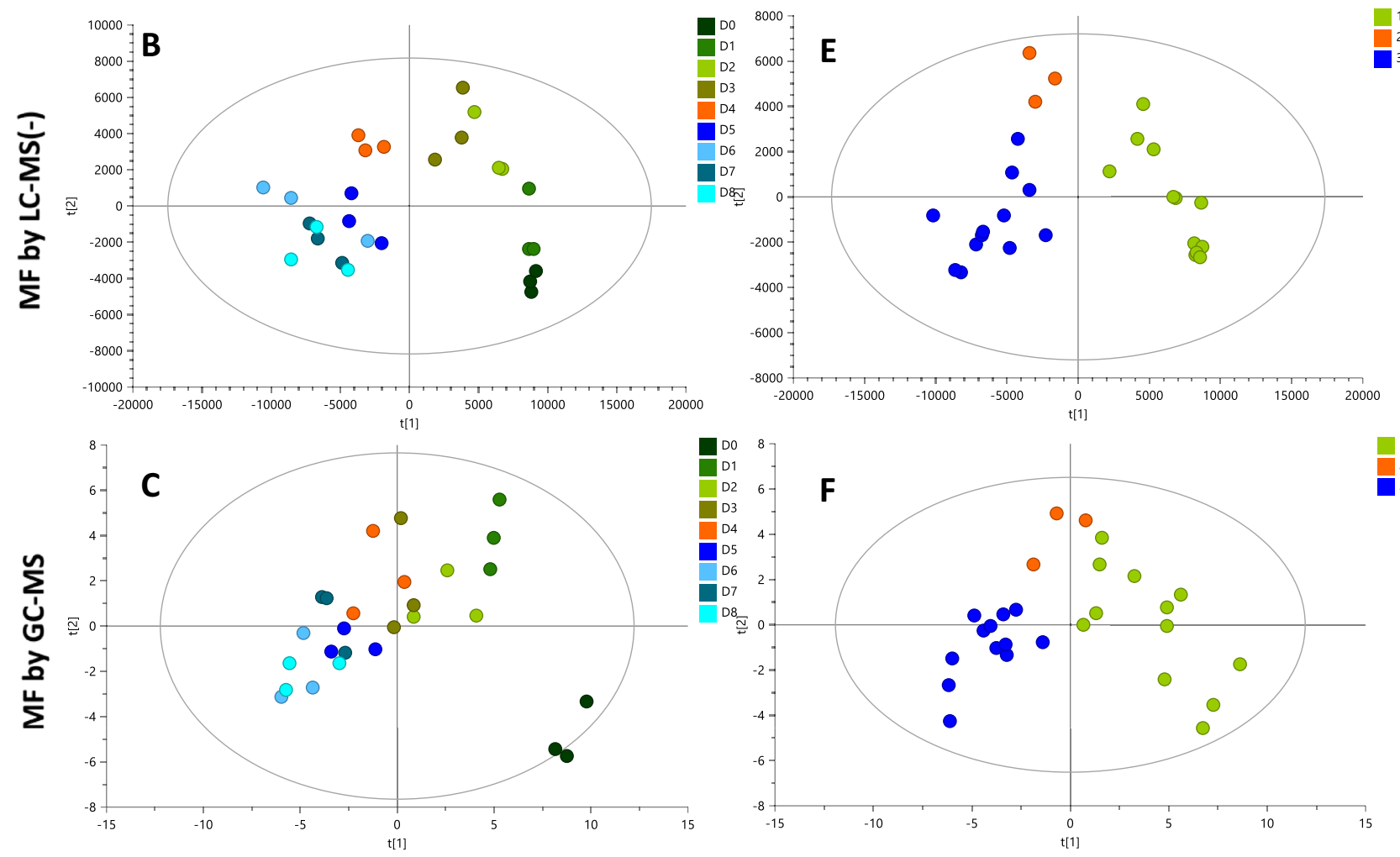

Figure 3. PLS-DA models for all cocoa fermentation samples and the proposed metabolic phases. ALL DAYS: (A) MF by LC-MS(+): $\mathrm{R}^{2}$ (cum): 0.838, $\mathrm{Q}^{2}$ (cum): 0.137, cv-anova: 0.995; (B) MF by LC-MS(-): $\mathrm{R}^{2}$ (cum): 0.696, Q2 (cum): 0.083, cv-anova: 0.993; (C) MF by GC-MS: $\mathrm{R}^{2}$ (cum): 0.442, $\mathrm{Q}^{2}$ (cum): 0.084, cv-anova: 0.951. PHASES: (D) MF by LC-MS(+): $\mathrm{R}^{2}$ (cum): 0.907, Q² (cum): 0.899, cv-anova: 6.296e-07; (E) MF by LC-MS(): $\mathrm{R}^{2}$ (cum): 0.903, $\mathrm{Q}^{2}$ (cum): 0.804, cv-anova: 0.00053; (F) MF by GC-MS: ${ }^{2}$ (cum): $0.415, \mathrm{Q}^{2}$ (cum): 0.45 , cv-anova: 0.0188 .

reactions ${ }^{36,37}$. The temperature over $45^{\circ} \mathrm{C}$ is a critical control point to determine the quality of the process, independently of the fermentation method, the region, the cocoa type, or the required fermentation time $e^{20,33,37-39}$.

As mentioned before, from the fifth day on, the temperature experienced minor changes and remained between $45-50{ }^{\circ} \mathrm{C}$ until fermentation ends. During this final phase, most microbial populations, and eventually its associated biochemical activity, decline as previously observed ${ }^{13,14,40}$. The relative abundance of microbial groups as yeast and LAB significantly decreases the last days of cocoa fermentation ${ }^{13,15,40}$. This drop is caused by a considerable decrease of fermentable sugars in the medium (e.g., glucose, fructose $)^{10,11}$. Also, temperature plays a relevant role in controlling microbial populations considering that LAB and yeast growth decreases dramatically over $40^{\circ} \mathrm{C}^{41,42}$. However, the elevated presence of lactic acid and oxygen prompts the growth of $\mathrm{AAB}$ that can resist higher temperature, producing acetic acid (an exothermic process) and releasing heat to the medium at a considerably lower rate but sufficient to maintain cocoa mass temperature relatively high, with a maximum variation of $5{ }^{\circ} \mathrm{C}^{35,43}$.

The temperature rise has a critical impact on flavor development during cocoa fermentation, as it guarantees the formation of molecules responsible for a high-quality sensorial profile ${ }^{44}$. The production of these compounds evidence the influence of temperature in metabolic activity across cocoa fermentation and the quality of the 


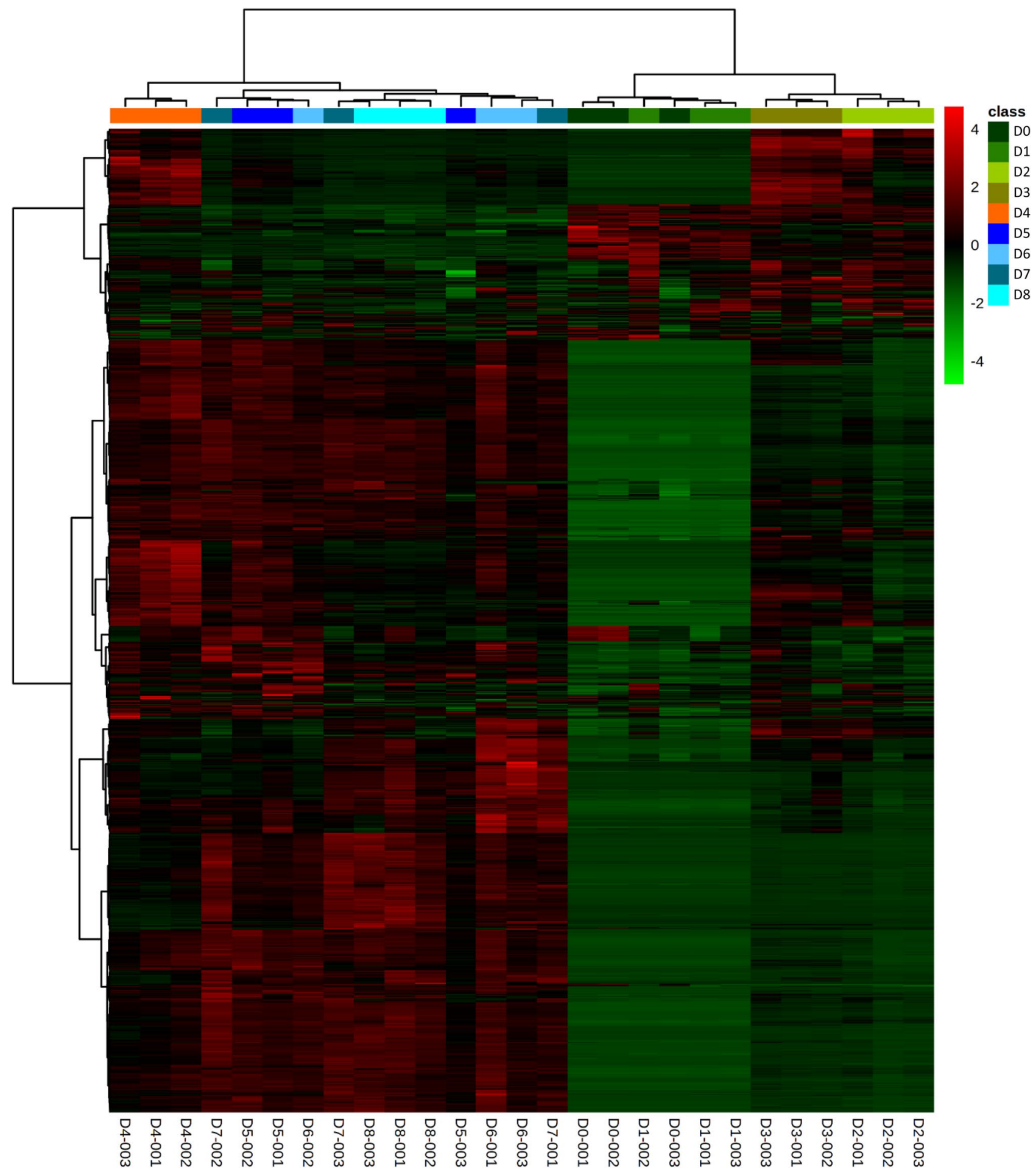

Figure 4. Heat map analysis of metabolite features detected in all analytical platforms for all fermentation days (MetaboAnalyst $5.0^{68}$ ). The color spectrum ranging from red to green indicates the range of high to low signal intensities for each metabolite.

$\operatorname{cocoa}^{10,44}$. A high temperature causes a significant diffusion of acetic acid, lactic acid, and ethanol into the beans promoting the degradation of flavonoids, reducing the bitterness and astringency of the cocoa ${ }^{1,39}$. Also, it changes more than $25^{\circ} \mathrm{C}$ during the fermentation ${ }^{10,37,44}$, stimulating a wide range of biochemical reactions and the growth of specific microorganisms in each increasing stage. These microorganisms carried out most of the transformations occurring in cocoa fermentation ${ }^{37,45}$. To achieve a high-quality sensorial profile, a proper succession of some specific microorganism genera is crucial. The development of this microbial progression depends on substrates present in the media and temperature ${ }^{39}$. 


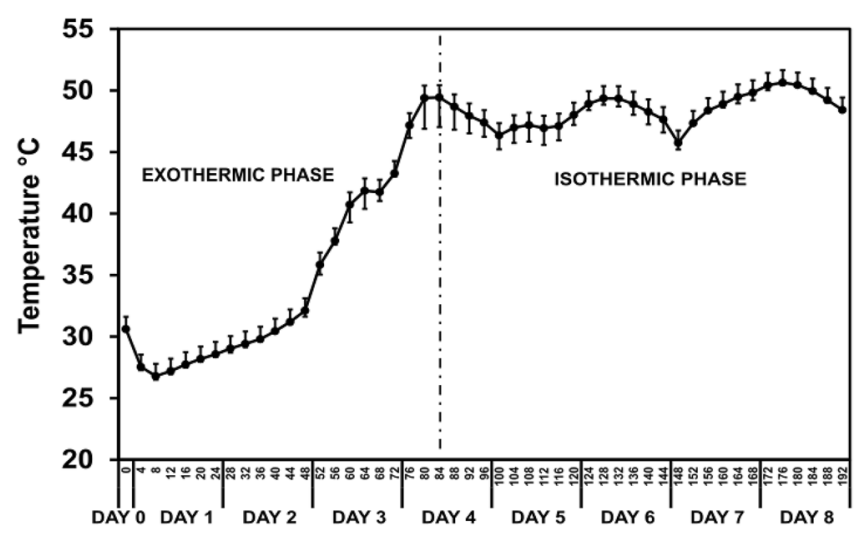

Figure 5. Temperature dynamic during the fermentation of fine-flavor cocoa. The dotted line divides cocoa fermentation temperature dynamics into two phases.

Additionally, temperature plays a crucial role in proteolysis. The temperature reaches more than $45^{\circ} \mathrm{C}$ during cocoa fermentation. This high temperature causes the activation of some native enzymes, and the protein heat denaturation produces a significant amount of peptides and amino acids ${ }^{25,46}$. These molecules are flavor precursors associated with the development of fruits and nutty notes in cocoa, qualities quite appreciated in the international markets ${ }^{10,47,48}$.

The variation in dominant groups of metabolites diverge between the two phases of differential metabolic activity. We analyzed the effect of the temperature dynamic in the metabolic profile of cocoa fermentation using a multiplatform metabolomics analysis. This approach allowed us to propose a new paradigm of the phases of cocoa fermentation based on the global metabolic activity instead of the variation in only a few metabolites. We propose two phases of cocoa fermentation based on the temperature dynamic: an exothermic phase from day 0 to day 3 and an isothermic phase from day 5 to day 8 . Once these phases were established, univariate ( $p$-value $<0.05$ from hypothesis testing) and multivariate (OPLS-DA models) analyses were performed to select the differential metabolites between each phase. For all analytical platforms, the OPLS$\mathrm{DA}$ analysis allowed modeling the differences between the two phases with statistically significant values for $\mathrm{R}^{2}$, $\mathrm{Q}^{2}$, CV-ANOVA (Fig. 6). As a result, 44, 65, 20 differential metabolites were identified in LC-QTOF-MS(+), LC-QTOF-MS(-), and GC-QTOF-MS(+), respectively.

Table 1 shows metabolites altered between the exothermic and isothermic phases of cocoa fermentation. The biggest group of metabolites differentially expressed correspond to amino acids, dipeptides, and tripeptides. The concentration of these 23 molecules increased in the isothermic phase. The formation of amino acids and peptides during cocoa fermentation is due to protein hydrolysis and denaturation processes. Protein content (e.g., albumin, prolamin, globulin, and glutein) represents $10-15 \%$ of dry unfermented cocoa beans ${ }^{46,47}$ and is significantly lower for fermented cocoa beans ${ }^{38,47,49}$. The drop in protein content, usually above $60 \%$, is caused by proteolysis during fermentation that involves two groups of native cocoa proteases: endoproteases and carboxypeptidases ${ }^{38,47,49}$. The optimal temperature for these enzymes is $45-50^{\circ} \mathrm{C}^{50,51}$, precisely the same temperature range of the fermentation the isothermic phase. Also, this temperature itself is accountable for protein denaturation, breaking them down into peptides or even amino acids ${ }^{25,49}$. This protein degradation linked to enzymatic hydrolysis and denaturation by heat in cocoa fermentation has been widely documented in several studies ${ }^{25,46-49}$.

Peptides and amino acids are highly relevant for the nutraceutical and sensorial properties of fine-flavor cocoa. Several cocoa peptides have been associated with bioactive properties such as antioxidant, antihypertensive, and antimicrobial ${ }^{52}$, although further research is still required. On the other hand, peptides and amino acids are precursors of pyrazines produced during drying and roasting through Maillard reactions ${ }^{5,49}$. These pyrazines are responsible for fine-flavor cocoa sensorial notes as fruity, floral, and $\operatorname{cocoa}^{5,53}$. In this regard, proteolysis could explain why cocoa fermentation in which temperature is consistently below $45^{\circ} \mathrm{C}$, the obtained chocolate usually has a poor sensorial profile.

Flavonoids are the second largest group of molecules differentially expressed with 18 compounds. In the isothermic phase, we observed a rise of different flavonoids such as dimers and trimers of procyanidins, polyphenol glycosides, and rhamnose-containing polyphenols. Also, our data show a decrease in some arecatannin types and butein and pelargonidin derivates. Although the overall content of flavonoids is expected to decrease throughout fermentation, these degradation processes can cause the emergence of polyphenolic dimers and trimers as well as polyphenolic acids as caffeic acid, benzoic acid, and coumaric acid ${ }^{54,55}$. For instance, oxidation and polyphenol oxidase hydrolysis of complex flavonoids such as anthocyanins, procyanidins, epigallocatechin, and kaempferol results in the formation of dimers and trimers of procyanidins and rhamnose-containing polyphenols ${ }^{54,55}$. However, these derivates tend to have lower bioactivity, leading to a significant drop in the bioactive properties of cocoa throughout fermentation, as previously reported ${ }^{8,38,56}$. Polyphenol degradation and eventual derivates formation can be more pronounced at high temperatures ${ }^{56,57}$. 
A.

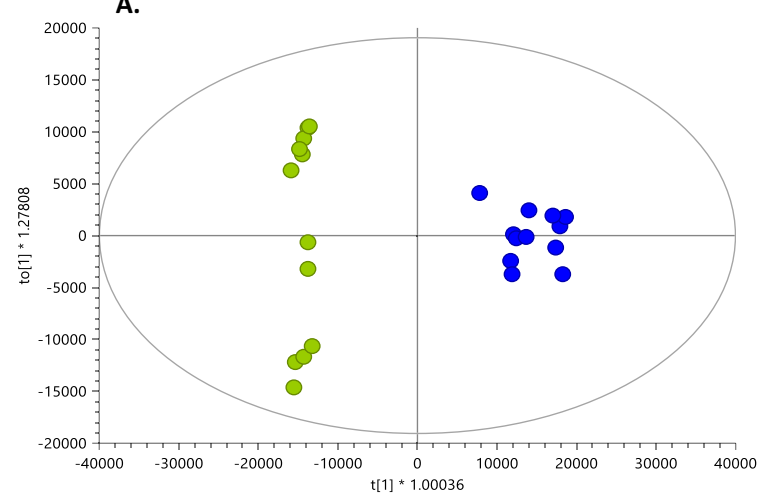

B.

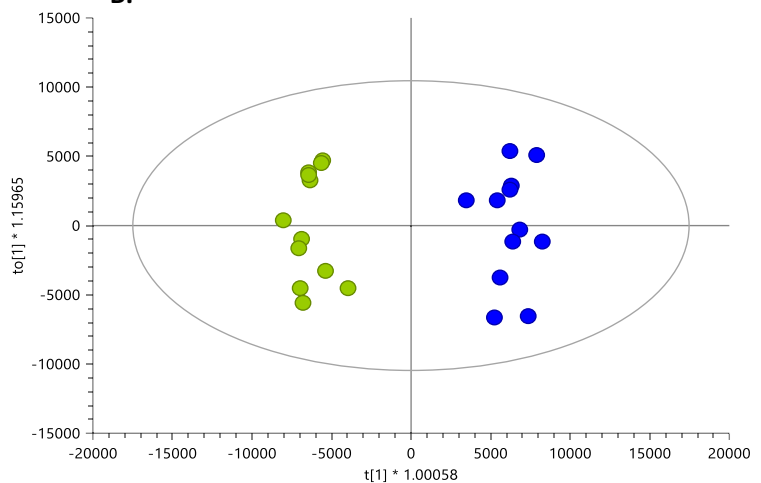

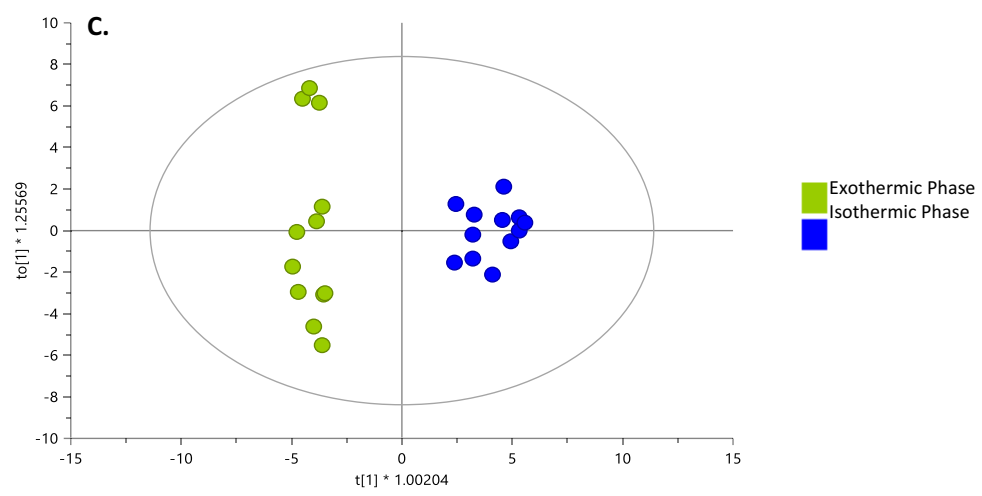

Figure 6. OPLS-DA models for two phases. (A) MF by LC-MS(+): $\mathrm{R}_{(\mathrm{cum})}^{2}: 0.804, \mathrm{Q}^{2}$ (cum): 0.962 , cv-anova: $3.58 \mathrm{e}-13$; (B) MF by LC-MS(-): $\mathrm{R}_{(\text {cum })}: 0.739, \mathrm{Q}^{2}{ }_{(\text {cum })}: 0.96$, cv-anova: $5.67 \mathrm{e}-07$; (C) MF by GC-MS: $\mathrm{R}_{(\text {cum) }}^{2}$ : $0.702, \mathrm{Q}^{2}$ (cum) $: 0.864$, cv-anova: $5.86 \mathrm{e}-12$.

Contrasting that, carbohydrates are the compound group with a higher number of decreasing concentration metabolites from the exothermic to isothermic phase. These metabolites are a primary substrate for many yeasts and bacteria, eventually generating a rise in different organic acids beyond traditional ones (e.g., lactic acid, acetic acid) like benzoic acid, caffeic acid, coumaric acid, oxoglutaric acid, and salicylic acid, as our data revealed. The carbohydrates transformation into organic acids is more intense during the exothermic than isothermic phase due to temperatures under $40^{\circ} \mathrm{C}$ and high content of pulp rich in carbohydrates ${ }^{11,21,39}$. These conditions facilitate yeast and bacteria growth as Saccharomyces, Candida, Mallasezia, Hanseniospora, Lactobacillus, and Bacillus produce organic acids as part of their central and secondary metabolism ${ }^{13,35,36,40,58}$.

Other small metabolite groups as phenols, coumarins, terpenoids, fatty acyls, and lipids were also found to varybetween the two phases. These compounds are likely a byproduct of the degradation of complex molecules as polyphenols using the central and secondary metabolism of many microorganisms associated with cocoa fermentations $\mathbf{s}^{13,40,54}$. For instance, the yeast of genus such as Mallasezia, previously reported in cocoa fermentation, is highly active in the metabolism of lipids and fatty acyls ${ }^{13}$. However, as the link between microorganismsmetabolites is still not elucidated, further research is required to dissect the connection between microbial populations and altered metabolites during cocoa fermentations.

Changes in the concentration of relevant metabolites (i.e., flavor precursors and bioactive compounds) were observed during spontaneous fermentation of fine-flavor cocoa. To better understand the development of some sensorial notes associated with fine-flavor cocoa (i.e., fruity, floral, and chocolate notes), we performed a search in the database FlavorDB ${ }^{53}$ using the list of altered and annotated compounds. We found a rise between the exothermic and isothermic phases of cedrol, irone, acetophenone, coumaric acid, maltol, vanillin, vanillin isobutyrate, and methylcoumarin (Fig. 7) associated with fine-flavor cocoa sensorial notes ${ }^{5,53}$. Nevertheless, we also observed a significant increase in phenol, coumarin, benzoic acid, and salicylic acid. These molecules produce undesirable flavors previously associated with green, astringent, and bitter attributes (Fig. 8) $)^{5,53}$.

Interestingly, we also observed an increase in some specific flavonoids with documented bioactive properties from the exothermic to isothermic phase. For example, catechin, epicatechin, Resveratrol 3-sulfate, Isoflavonoid $O$-glycoside, and a group of procyanidins dimers and trimers experienced a considerable increase over fermentation (Fig. 9). These compounds are widely known due to their antioxidant properties ${ }^{8,57}$. Similarly, other metabolites as dopamine, nicotinamide riboside, and aspartic acid were observed to increase throughout cocoa fermentation. An attractive potential emerges from these molecules because they can act as neurotransmitters ${ }^{59}$, cardiovascular regulator ${ }^{60}$, and hormone regulator ${ }^{61}$, respectively. These bioactive molecules could be produced 


\begin{tabular}{|c|c|c|c|c|c|c|c|c|c|c|c|}
\hline Compound name & $\begin{array}{l}\text { Molecular } \\
\text { Formula }\end{array}$ & $\begin{array}{l}\text { Molecular } \\
\text { weight (DB) } \\
\mathrm{g} / \mathrm{mol}\end{array}$ & RT (min) & $\begin{array}{l}\text { Mass error } \\
\text { (ppm) }\end{array}$ & $\begin{array}{l}\text { Analytical } \\
\text { platform }\end{array}$ & DET & CON & $\begin{array}{l}\text { CV in QC } \\
(\%)\end{array}$ & Fold Change & VIP Value & $\begin{array}{l}p \text {-value with } \\
\text { FDR }\end{array}$ \\
\hline \multicolumn{12}{|c|}{ Amino acids, peptides, and derivatives } \\
\hline Alanine & $\mathrm{C}_{3} \mathrm{H}_{7} \mathrm{NO}_{2}$ & 89.0476 & 7.553 & - & $\begin{array}{l}\text { GC-QTOF- } \\
\text { MS }\end{array}$ & EI & Identified & 1.85 & 1.3 & 1.098 & 0.0034 \\
\hline Aspartic acid & $\mathrm{C}_{4} \mathrm{H}_{7} \mathrm{NO}_{4}$ & 133.0375 & 8.11 & 7 & \begin{tabular}{|l|} 
LC-QTOF- \\
MS \\
\end{tabular} & ESI- & Putative & 1.25 & 6.6 & 2.650 & 0.00019 \\
\hline Glutamic acid & $\mathrm{C}_{5} \mathrm{H}_{9} \mathrm{NO}_{4}$ & 47.1293 & 14.55 & - & $\begin{array}{l}\text { GC-QTOF- } \\
\text { MS }\end{array}$ & EI & Identified & 2.9 & 2.1 & 1.34247 & - \\
\hline Glutamine & $\mathrm{C}_{5} \mathrm{H}_{10} \mathrm{~N}_{2} \mathrm{O}_{3}$ & 146.0691 & 1.81 & 3 & $\begin{array}{l}\text { LC-QTOF- } \\
\text { MS } \\
\text { GC-QTOF- } \\
\text { MS } \\
\end{array}$ & $\begin{array}{l}\text { ESI+ } \\
\text { EI }\end{array}$ & \begin{tabular}{|l} 
Putative \\
Identified
\end{tabular} & 1.25 & 5.3 & 2.336 & $7.22 \mathrm{E}-05$ \\
\hline Leucine & $\mathrm{C}_{6} \mathrm{H}_{13} \mathrm{NO}_{2}$ & 131.0946 & 2.08 & 5 & $\begin{array}{l}\text { LC-QTOF- } \\
\text { MS }\end{array}$ & ESI- & Putative & 2.57 & 3.7 & 1.524 & $9.58 \mathrm{E}-05$ \\
\hline Phenylalanine & $\mathrm{C}_{9} \mathrm{H}_{11} \mathrm{NO}_{2}$ & 165.079 & 3.44 & 2 & $\begin{array}{l}\text { LC-QTOF- } \\
\text { MS } \\
\text { GC-QTOF- } \\
\text { MS } \\
\end{array}$ & $\begin{array}{l}\text { ESI }+ \\
\text { EI }\end{array}$ & \begin{tabular}{|l} 
Putative \\
Identified
\end{tabular} & 2.42 & 3.3 & 1.537 & $9.58 \mathrm{E}-05$ \\
\hline Proline & $\mathrm{C}_{5} \mathrm{H}_{9} \mathrm{NO}_{2}$ & 115.0633 & 2.69 & 5 & $\begin{array}{l}\text { LC-QTOF- } \\
\text { MS } \\
\text { GC-QTOF- } \\
\text { MS }\end{array}$ & $\begin{array}{l}\text { ESI+ } \\
\text { EI }\end{array}$ & \begin{tabular}{|l} 
Putative \\
Identified
\end{tabular} & 13.58 & 3.3 & 1.790 & 0.00011 \\
\hline Serine & $\mathrm{C}_{3} \mathrm{H}_{7} \mathrm{NO}_{3}$ & 105.0926 & 11.32 & - & $\begin{array}{l}\text { GC-QTOF- } \\
\text { MS }\end{array}$ & EI & Identified & 3.3 & 5.1 & 1.61403 & - \\
\hline Threonine & $\mathrm{C}_{4} \mathrm{H}_{9} \mathrm{NO}_{3}$ & 119.1192 & 11.69 & - & $\begin{array}{l}\text { GC-QTOF- } \\
\text { MS }\end{array}$ & EI & Identified & 1.4 & 5.4 & 1.6294 & - \\
\hline Tyramine & $\mathrm{C}_{8} \mathrm{H}_{11} \mathrm{NO}$ & 137.0841 & 2.81 & 2 & \begin{tabular}{|l|} 
LC-QTOF- \\
MS \\
\end{tabular} & ESI + & Putative & 2.88 & 4.6 & 1.839 & $7.22 \mathrm{E}-05$ \\
\hline Tyrosine & $\mathrm{C}_{9} \mathrm{H}_{11} \mathrm{NO}_{3}$ & 181.0739 & 1.83 & 3 & \begin{tabular}{|l} 
LC-QTOF- \\
MS \\
\end{tabular} & ESI- & Putative & 2.57 & 2.5 & 1.424 & $8.61 \mathrm{E}-07$ \\
\hline $\begin{array}{l}\text { Caffeoyl aspartic } \\
\text { acid }\end{array}$ & $\mathrm{C}_{13} \mathrm{H}_{13} \mathrm{NO}_{7}$ & 295.0692 & 8.12 & 2 & $\begin{array}{l}\text { LC-QTOF- } \\
\text { MS }\end{array}$ & ESI- & Putative & 1.78 & 8.8 & 3.820 & 0.00019 \\
\hline AlanylProline & $\mathrm{C}_{8} \mathrm{H}_{14} \mathrm{~N}_{2} \mathrm{O}_{3}$ & 186.1004 & 2.26 & 2 & \begin{tabular}{|l|} 
LC-QTOF- \\
MS \\
\end{tabular} & ESI + & Putative & 7.00 & 7.0 & 2.000 & 9.59 E-09 \\
\hline ArginylProline & $\mathrm{C}_{11} \mathrm{H}_{21} \mathrm{~N}_{5} \mathrm{O}_{3}$ & 271.1644 & 1.94 & 6 & $\begin{array}{l}\text { LC-QTOF- } \\
\text { MS }\end{array}$ & ESI+ & Putative & 4.03 & 28.8 & 1.627 & $7.22 \mathrm{E}-05$ \\
\hline $\begin{array}{l}\text { Glutamylglu- } \\
\text { tamine }\end{array}$ & $\mathrm{C}_{10} \mathrm{H}_{17} \mathrm{~N}_{3} \mathrm{O}_{6}$ & 275.1117 & 1.9 & 0 & $\begin{array}{l}\text { LC-QTOF- } \\
\text { MS }\end{array}$ & ESI- & Putative & 1.99 & 11.7 & 1.161 & $9.10 \mathrm{E}-05$ \\
\hline Glutamylleucine & $\mathrm{C}_{11} \mathrm{H}_{20} \mathrm{~N}_{2} \mathrm{O}_{5}$ & 260.1372 & 2.07 & 2 & \begin{tabular}{|l|} 
LC-QTOF- \\
MS \\
\end{tabular} & ESI \pm & MS/MS & 1.42 & 6.1 & 1.744 & $7.22 \mathrm{E}-05$ \\
\hline LeucylThreonine & $\mathrm{C}_{10} \mathrm{H}_{20} \mathrm{~N}_{2} \mathrm{O}_{4}$ & 232.1423 & 1.72 & 2 & \begin{tabular}{|l|} 
LC-QTOF- \\
MS \\
\end{tabular} & ESI + & Putative & 2.44 & 2.5 & 1.561 & 0.00021 \\
\hline ProlylLysine & $\mathrm{C}_{11} \mathrm{H}_{21} \mathrm{~N}_{3} \mathrm{O}_{3}$ & 243.1583 & 2.52 & 2 & $\begin{array}{l}\text { LC-QTOF- } \\
\text { MS }\end{array}$ & ESI- & Putative & 3.17 & 6.4 & 1.794 & $9.10 \mathrm{E}-05$ \\
\hline ProlylSerine & $\mathrm{C}_{8} \mathrm{H}_{14} \mathrm{~N}_{2} \mathrm{O}_{4}$ & 202.0954 & 2.07 & 2 & $\begin{array}{l}\text { LC-QTOF- } \\
\text { MS }\end{array}$ & ESI + & Putative & 1.90 & 26.0 & 2.170 & $7.22 \mathrm{E}-05$ \\
\hline Tripeptide 1 & $\mathrm{C}_{17} \mathrm{H}_{29} \mathrm{~N}_{7} \mathrm{O}_{5}$ & 411.223 & 1.64 & 7 & $\begin{array}{l}\text { LC-QTOF- } \\
\text { MS }\end{array}$ & ESI \pm & Putative & 1.80 & 10.0 & 2.162 & $7.22 \mathrm{E}-05$ \\
\hline Tripeptide 2 & $\mathrm{C}_{13} \mathrm{H}_{25} \mathrm{~N}_{3} \mathrm{O}_{5}$ & 303.1794 & 1.88 & 0 & $\begin{array}{l}\text { LC-QTOF- } \\
\text { MS }\end{array}$ & ESI \pm & Putative & 1.61 & 2.6 & 1.649 & 0.00086 \\
\hline Tripeptide 3 & $\mathrm{C}_{16} \mathrm{H}_{29} \mathrm{~N}_{5} \mathrm{O}_{7}$ & 403.2067 & 1.93 & 1 & $\begin{array}{l}\text { LC-QTOF- } \\
\text { MS }\end{array}$ & ESI \pm & Putative & 1.52 & 12.6 & 2.848 & $7.22 \mathrm{E}-05$ \\
\hline Tripeptide 4 & $\mathrm{C}_{17} \mathrm{H}_{22} \mathrm{~N}_{4} \mathrm{O}_{8}$ & 410.1438 & 3.28 & 0 & $\begin{array}{l}\text { LC-QTOF- } \\
\text { MS }\end{array}$ & ESI- & Putative & 3.43 & 9.7 & 1.052 & $9.10 \mathrm{E}-05$ \\
\hline \multicolumn{12}{|l|}{ Organic acids } \\
\hline Avenanthramide 2 & $\mathrm{C}_{18} \mathrm{H}_{17} \mathrm{NO}_{7}$ & 359.1005 & 11.98 & 2 & $\begin{array}{l}\text { LC-QTOF- } \\
\text { MS }\end{array}$ & ESI- & Putative & 3.38 & 14.5 & 1.187 & $9.58 \mathrm{E}-05$ \\
\hline Benzoic acid & $\mathrm{C}_{7} \mathrm{H}_{6} \mathrm{O}_{2}$ & 122.0368 & 11.39 & 5 & $\begin{array}{l}\text { LC-QTOF- } \\
\text { MS }\end{array}$ & ESI+ & Putative & 1.42 & 12.6 & 2.364 & 0.00013 \\
\hline Caffeic acid & $\mathrm{C}_{9} \mathrm{H}_{8} \mathrm{O}_{4}$ & 180.0423 & 8.1 & 2 & \begin{tabular}{|l|} 
LC-QTOF- \\
MS \\
\end{tabular} & ESI + & MS/MS & 0.86 & 4.8 & 4.299 & 0.00016 \\
\hline Coumaric acid & $\mathrm{C}_{9} \mathrm{H}_{8} \mathrm{O}_{3}$ & 164.0473 & 11.39 & 4 & $\begin{array}{l}\text { LC-QTOF- } \\
\text { MS }\end{array}$ & ESI + & MS/MS & 2.07 & 10.0 & 1.888 & 0.00013 \\
\hline Oxoglutaric acid & $\mathrm{C}_{5} \mathrm{H}_{6} \mathrm{O}_{5}$ & 146.0215 & 1.58 & 5 & \begin{tabular}{|l|} 
LC-QTOF- \\
MS \\
\end{tabular} & ESI- & Putative & 6.36 & 1.5 & 1.079 & $3.99 \mathrm{E}-05$ \\
\hline Salicylic acid & $\mathrm{C}_{7} \mathrm{H}_{6} \mathrm{O}_{3}$ & 138.0317 & 11.4 & 3 & \begin{tabular}{|l|} 
LC-QTOF- \\
MS \\
\end{tabular} & ESI- & Putative & 2.08 & 13.8 & 1.691 & 0.00015 \\
\hline Sesamol & $\mathrm{C}_{7} \mathrm{H}_{6} \mathrm{O}_{3}$ & 138.0317 & 11.39 & 4 & $\begin{array}{l}\text { LC-QTOF- } \\
\text { MS }\end{array}$ & ESI \pm & Putative & 1.28 & 10.3 & 3.352 & 0.00013 \\
\hline
\end{tabular}




\begin{tabular}{|c|c|c|c|c|c|c|c|c|c|c|c|}
\hline Compound name & $\begin{array}{l}\text { Molecular } \\
\text { Formula }\end{array}$ & $\begin{array}{l}\text { Molecular } \\
\text { weight (DB) } \\
\mathrm{g} / \mathrm{mol}\end{array}$ & RT (min) & $\begin{array}{l}\text { Mass error } \\
\text { (ppm) }\end{array}$ & $\begin{array}{l}\text { Analytical } \\
\text { platform }\end{array}$ & DET & CON & $\begin{array}{l}\mathrm{CV} \text { in QC } \\
(\%)\end{array}$ & Fold Change & VIP Value & $\begin{array}{l}p \text {-value with } \\
\text { FDR }\end{array}$ \\
\hline $\begin{array}{l}\text { Tetrahydroxychal- } \\
\text { cone 4'-O-(2"- } \\
O \text {-acetyl-6"- } \\
\text { O-cinnamoyl) } \\
\text { glucoside }\end{array}$ & $\mathrm{C}_{32} \mathrm{H}_{30} \mathrm{O}_{12}$ & 606.1737 & 12.64 & 1 & $\begin{array}{l}\text { LC-QTOF- } \\
\text { MS }\end{array}$ & ESI- & Putative & 3.81 & 14.1 & 1.434 & $9.10 \mathrm{E}-05$ \\
\hline Tumonoic Acid H & $\mathrm{C}_{26} \mathrm{H}_{45} \mathrm{NO}_{7}$ & 483.3196 & 4.62 & 5 & $\begin{array}{l}\text { LC-QTOF- } \\
\text { MS }\end{array}$ & ESI + & Putative & 3.06 & 12.2 & 2.671 & $7.20 \mathrm{E}-05$ \\
\hline \multicolumn{12}{|c|}{ Carbonyl compounds } \\
\hline Acetophenone & $\mathrm{C}_{8} \mathrm{H}_{8} \mathrm{O}$ & 120.0575 & 12.26 & 6 & $\begin{array}{l}\text { LC-QTOF- } \\
\text { MS }\end{array}$ & ESI- & Putative & 2.51 & 6.8 & 1.271 & 0.0011 \\
\hline Acetol & $\mathrm{C}_{3} \mathrm{H}_{6} \mathrm{O}_{2}$ & 74.0785 & 13.29 & & $\begin{array}{l}\text { GC-QTOF- } \\
\text { MS }\end{array}$ & EI & Identified & 1.7 & 5.6 & 1.23759 & 0.0001 \\
\hline $\begin{array}{l}\text { Hydroxyaceto- } \\
\text { phenone }\end{array}$ & $\mathrm{C}_{8} \mathrm{H}_{8} \mathrm{O}_{2}$ & 136.0524 & 8.11 & 6 & $\begin{array}{l}\text { LC-QTOF- } \\
\text { MS }\end{array}$ & ESI- & Putative & 2.04 & 6.1 & 1.877 & 0.00015 \\
\hline \multicolumn{12}{|l|}{ Carbohydrates } \\
\hline Anhydrofructose & $\mathrm{C}_{6} \mathrm{H}_{10} \mathrm{O}_{5}$ & 162.0528 & 1.16 & 4 & $\begin{array}{l}\text { LC-QTOF- } \\
\text { MS }\end{array}$ & ESI+ & Putative & 6.46 & 0.2 & 1.540 & $7.22 \mathrm{E}-05$ \\
\hline Arabitol//Ribitol & $\mathrm{C}_{5} \mathrm{H}_{12} \mathrm{O}_{5}$ & 152.0685 & 15.59 & - & $\begin{array}{l}\text { GC-QTOF- } \\
\text { MS }\end{array}$ & EI & Identified & 0.0 & 2.0 & 1.04962 & 0.00016 \\
\hline Decarboxybetanin & $\mathrm{C}_{23} \mathrm{H}_{27} \mathrm{~N}_{2} \mathrm{O}_{11}$ & 507.1615 & 4.42 & 4 & $\begin{array}{l}\text { LC-QTOF- } \\
\text { MS }\end{array}$ & ESI- & Putative & 1.63 & 15.0 & 1.158 & $9.10 \mathrm{E}-05$ \\
\hline $\begin{array}{l}\text { Dihydrocaffeic } \\
\text { acid 3-O-glucu- } \\
\text { ronide }\end{array}$ & $\mathrm{C}_{15} \mathrm{H}_{18} \mathrm{O}_{10}$ & 358.09 & 1.14 & 2 & $\begin{array}{l}\text { LC-QTOF- } \\
\text { MS }\end{array}$ & ESI+ & MS/MS & 2.33 & 0.3 & 2.240 & $5.04 \mathrm{E}-06$ \\
\hline $\begin{array}{l}\text { Dihydroxyphenyl } \\
\text { 1-O-(6-O-gal- } \\
\text { loyl-beta-D-glu- } \\
\text { copyranoside) }\end{array}$ & $\mathrm{C}_{19} \mathrm{H}_{20} \mathrm{O}_{12}$ & 440.0955 & 1.14 & 5 & $\begin{array}{l}\text { LC-QTOF- } \\
\text { MS }\end{array}$ & ESI- & Putative & 1.39 & 0.3 & 1.271 & 0.00015 \\
\hline Gluconic acid & $\mathrm{C}_{6} \mathrm{H}_{12} \mathrm{O}_{7}$ & 196.0583 & 1.13 & 6 & $\begin{array}{l}\text { LC-QTOF- } \\
\text { MS }\end{array}$ & ESI- & Putative & 1.27 & 0.7 & 2.212 & - \\
\hline $\begin{array}{l}\text { Glucose // } \\
\text { Galactose }\end{array}$ & $\mathrm{C}_{6} \mathrm{H}_{12} \mathrm{O}_{6}$ & 180.0634 & 17.61 & - & $\begin{array}{l}\text { GC-QTOF- } \\
\text { MS }\end{array}$ & EI & Identified & 2.6 & 2.1 & 1.46337 & - \\
\hline Maltose & $\mathrm{C}_{12} \mathrm{H}_{22} \mathrm{O}_{11}$ & 342.2965 & 24.86 & - & $\begin{array}{l}\text { GC-QTOF- } \\
\text { MS }\end{array}$ & EI & Identified & 4.7 & 0.0 & 1.07032 & - \\
\hline Mannitol & $\mathrm{C}_{6} \mathrm{H}_{14} \mathrm{O}_{6}$ & 182.1718 & 17.8 & - & $\begin{array}{l}\text { GC-QTOF- } \\
\text { MS }\end{array}$ & EI & Identified & 3.8 & 0.8 & - & 0.0178867 \\
\hline Raffinose & $\mathrm{C}_{18} \mathrm{H}_{32} \mathrm{O}_{16}$ & 504.169 & 1.13 & 1 & $\begin{array}{l}\text { LC-QTOF- } \\
\text { MS }\end{array}$ & ESI- & Putative & 1.70 & 0.1 & 2.429 & $1.22 \mathrm{E}-05$ \\
\hline $\begin{array}{l}\text { Ribose // Lyxose } \\
\text { // Arabinose }\end{array}$ & $\mathrm{C}_{5} \mathrm{H}_{10} \mathrm{O}_{5}$ & 150.0528 & 15.1 & - & $\begin{array}{l}\text { GC-QTOF- } \\
\text { MS }\end{array}$ & EI & Identified & 1.4 & 1.3 & 1.17136 & - \\
\hline Sorbitol & $\mathrm{C}_{6} \mathrm{H}_{14} \mathrm{O}_{6}$ & 182.1718 & 17.86 & - & $\begin{array}{l}\text { GC-QTOF- } \\
\text { MS }\end{array}$ & EI & Identified & 3.5 & 0.8 & 1.2679 & - \\
\hline Sorbosone & $\mathrm{C}_{6} \mathrm{H}_{10} \mathrm{O}_{6}$ & 178.0477 & 1.21 & 6 & $\begin{array}{l}\text { LC-QTOF- } \\
\text { MS }\end{array}$ & ESI- & Putative & 2.87 & 0.5 & 1.040 & 0.00019 \\
\hline $\begin{array}{l}\text { Stachyose // } \\
\text { Maltotetraose }\end{array}$ & $\mathrm{C}_{24} \mathrm{H}_{42} \mathrm{O}_{21}$ & 666.2219 & 1.1 & 0 & $\begin{array}{l}\text { LC-QTOF- } \\
\text { MS }\end{array}$ & ESI- & Putative & 1.68 & 0.2 & 2.581 & $1.09 \mathrm{E}-07$ \\
\hline \multicolumn{12}{|l|}{ Phenols } \\
\hline Catechol & $\mathrm{C}_{6} \mathrm{H}_{6} \mathrm{O}_{2}$ & 110.1106 & 10.59 & & $\begin{array}{l}\text { GC-QTOF- } \\
\text { MS }\end{array}$ & EI & Identified & 2.8 & 1.5 & 1.22319 & 0.011 \\
\hline Dopamine & $\mathrm{C}_{8} \mathrm{H}_{11} \mathrm{NO}_{2}$ & 153.079 & 10.11 & 3 & $\begin{array}{l}\text { LC-QTOF- } \\
\text { MS }\end{array}$ & ESI+ & Putative & 3.11 & 6.1 & 1.570 & $7.22 \mathrm{E}-05$ \\
\hline Methylcatechol & $\mathrm{C}_{7} \mathrm{H}_{8} \mathrm{O}_{2}$ & 124.0524 & 11.4 & 6 & $\begin{array}{l}\text { LC-QTOF- } \\
\text { MS }\end{array}$ & ESI- & Putative & 2.31 & 11.9 & 1.249 & 0.00015 \\
\hline Phenol & $\mathrm{C}_{6} \mathrm{H}_{6} \mathrm{O}$ & 94.0419 & 3.42 & 8 & $\begin{array}{l}\text { LC-QTOF- } \\
\text { MS }\end{array}$ & ESI+ & Putative & 2.23 & 2.5 & 2.902 & $8.70 \mathrm{E}-05$ \\
\hline Pyrocatechol & $\mathrm{C}_{6} \mathrm{H}_{6} \mathrm{O}_{2}$ & 110.0368 & 11.4 & 6 & \begin{tabular}{|l|} 
LC-QTOF- \\
MS \\
\end{tabular} & ESI- & Putative & 2.88 & 12.3 & 1.234 & 0.00015 \\
\hline Vanillin & $\mathrm{C}_{8} \mathrm{H}_{8} \mathrm{O}_{3}$ & 152.0473 & 8.1 & 3 & $\begin{array}{l}\text { LC-QTOF- } \\
\text { MS }\end{array}$ & ESI+ & MS/MS & 1.29 & 5.3 & 2.567 & 0.00016 \\
\hline $\begin{array}{l}\text { Vanillin isobu- } \\
\text { tyrate }\end{array}$ & $\mathrm{C}_{12} \mathrm{H}_{14} \mathrm{O}_{4}$ & 222.0892 & 11.4 & 3 & $\begin{array}{l}\text { LC-QTOF- } \\
\text { MS }\end{array}$ & ESI- & Putative & 1.44 & 12.7 & 1.213 & 0.00015 \\
\hline \multicolumn{12}{|c|}{ Indoles and derivatives } \\
\hline Indolamine & $\mathrm{C}_{8} \mathrm{H}_{8} \mathrm{~N}_{2}$ & 132.0687 & 8.12 & 3 & $\begin{array}{l}\text { LC-QTOF- } \\
\text { MS }\end{array}$ & ESI- & Putative & 8.33 & 4.7 & 1.840 & 0.00019 \\
\hline Indoleacrylic acid & $\mathrm{C}_{11} \mathrm{H}_{9} \mathrm{NO}_{2}$ & 187.0633 & 10.2 & 3 & $\begin{array}{l}\text { LC-QTOF- } \\
\text { MS }\end{array}$ & ESI+ & Putative & 1.93 & 8.5 & 1.808 & $7.22 \mathrm{E}-05$ \\
\hline \multicolumn{12}{|l|}{\begin{tabular}{|l} 
Phenylpropanoids \\
\end{tabular}} \\
\hline Continued & & & & & & & & & & & \\
\hline
\end{tabular}




\begin{tabular}{|c|c|c|c|c|c|c|c|c|c|c|c|}
\hline Compound name & \begin{tabular}{|l} 
Molecular \\
Formula
\end{tabular} & $\begin{array}{l}\text { Molecular } \\
\text { weight (DB) } \\
\mathrm{g} / \mathrm{mol}\end{array}$ & RT (min) & $\begin{array}{l}\text { Mass error } \\
(\mathrm{ppm})\end{array}$ & $\begin{array}{l}\text { Analytical } \\
\text { platform }\end{array}$ & DET & CON & $\begin{array}{l}\mathrm{CV} \text { in } \mathrm{QC} \\
(\%)\end{array}$ & Fold Change & VIP Value & $\begin{array}{l}p \text {-value with } \\
\text { FDR }\end{array}$ \\
\hline Schizandrin & $\mathrm{C}_{24} \mathrm{H}_{32} \mathrm{O}_{7}$ & 432.2148 & 10.91 & 7 & $\begin{array}{l}\text { LC-QTOF- } \\
\text { MS }\end{array}$ & ESI \pm & Putative & 1.18 & 6.8 & 2.963 & $7.20 \mathrm{E}-05$ \\
\hline Sinapine & $\mathrm{C}_{16} \mathrm{H}_{24} \mathrm{NO}_{5}$ & 310.1654 & 6.58 & 3 & $\begin{array}{l}\text { LC-QTOF- } \\
\text { MS }\end{array}$ & ESI- & Putative & 1.93 & 15.5 & 1.195 & $9.10 \mathrm{E}-05$ \\
\hline \multicolumn{12}{|l|}{ Pyridine nucleotides } \\
\hline $\begin{array}{l}\text { Nicotinamide } \\
\text { ribotide }\end{array}$ & $\mathrm{C}_{11} \mathrm{H}_{15} \mathrm{~N}_{2} \mathrm{O}_{8} \mathrm{P}$ & 334.0566 & 10.39 & 8 & $\begin{array}{l}\text { LC-QTOF- } \\
\text { MS }\end{array}$ & ESI- & Putative & 1.55 & 10.1 & 1.582 & 0.00024 \\
\hline \multicolumn{12}{|l|}{ Coumarins } \\
\hline Coumarin & $\mathrm{C}_{9} \mathrm{H}_{6} \mathrm{O}_{2}$ & 146.0368 & 10.47 & 4 & \begin{tabular}{|l|} 
LC-QTOF- \\
MS \\
\end{tabular} & ESI + & MS/MS & 1.56 & 1.7 & 1.756 & 0.011 \\
\hline Methylcoumarin & $\mathrm{C}_{10} \mathrm{H}_{8} \mathrm{O}_{2}$ & 160.0524 & 11.4 & 4 & $\begin{array}{l}\text { LC-QTOF- } \\
\text { MS }\end{array}$ & ESI- & Putative & 1.38 & 12.7 & 1.293 & 0.00015 \\
\hline Marmesin & $\mathrm{C}_{14} \mathrm{H}_{14} \mathrm{O}_{4}$ & 246.0892 & 9.44 & 2 & \begin{tabular}{|l|} 
LC-QTOF- \\
MS \\
\end{tabular} & ESI- & Putative & 5.47 & 16.6 & 1.452 & $9.10 \mathrm{E}-05$ \\
\hline Occidentoside & $\mathrm{C}_{36} \mathrm{H}_{32} \mathrm{O}_{15}$ & 704.1741 & 1.09 & 6 & $\begin{array}{l}\text { LC-QTOF- } \\
\text { MS }\end{array}$ & ESI + & MS/MS & 1.35 & 0.3 & 2.482 & $1.19 \mathrm{E}-07$ \\
\hline \multicolumn{12}{|l|}{ Flavonoids } \\
\hline Alkannin & $\mathrm{C}_{16} \mathrm{H}_{16} \mathrm{O}_{5}$ & 288.0998 & 12.48 & 1 & \begin{tabular}{|l|} 
LC-QTOF- \\
MS \\
\end{tabular} & ESI + & Putative & 3.67 & 3.0 & 1.649 & 0.0022 \\
\hline Arecatannin A2 & $\mathrm{C}_{60} \mathrm{H}_{50} \mathrm{O}_{24}$ & 1154.2692 & 12.09 & 2 & $\begin{array}{l}\text { LC-QTOF- } \\
\text { MS }\end{array}$ & ESI- & Putative & 2.14 & 0.7 & 1.224 & 0.044 \\
\hline Arecatannin A3 & $\mathrm{C}_{75} \mathrm{H}_{62} \mathrm{O}_{30}$ & 1442.3326 & 12.03 & 2 & \begin{tabular}{|l|} 
LC-QTOF- \\
MS \\
\end{tabular} & ESI- & Putative & 2.43 & 0.7 & 1.576 & 0.021 \\
\hline $\begin{array}{l}\text { A-type procyani- } \\
\text { din dimer }\end{array}$ & $\mathrm{C}_{30} \mathrm{H}_{24} \mathrm{O}_{12}$ & 576.1268 & 13.86 & 0 & \begin{tabular}{|l|} 
LC-QTOF- \\
MS \\
\end{tabular} & ESI- & Putative & 1.56 & 1.9 & 1.050 & 0.0045 \\
\hline $\begin{array}{l}\text { A-type procyani- } \\
\text { din dimer }\end{array}$ & $\mathrm{C}_{30} \mathrm{H}_{24} \mathrm{O}_{12}$ & 576.1268 & 12.48 & 1 & $\begin{array}{l}\text { LC-QTOF- } \\
\text { MS } \\
\end{array}$ & ESI+ & Putative & 1.53 & 3.1 & 1.635 & 0.00086 \\
\hline $\begin{array}{l}\text { B-type procyani- } \\
\text { din dimer }\end{array}$ & $\mathrm{C}_{30} \mathrm{H}_{26} \mathrm{O}_{12}$ & 578.1424 & 10.93 & 0 & $\begin{array}{l}\text { LC-QTOF- } \\
\text { MS }\end{array}$ & ESI- & Putative & 1.96 & 4.2 & 5.049 & 0.00081 \\
\hline $\begin{array}{l}\text { B-type procyani- } \\
\text { din dimer }\end{array}$ & $\mathrm{C}_{30} \mathrm{H}_{26} \mathrm{O}_{12}$ & 578.1424 & 11.15 & 0 & \begin{tabular}{|l|} 
LC-QTOF- \\
MS \\
\end{tabular} & ESI- & Putative & 2.17 & 4.9 & 2.153 & 0.00054 \\
\hline $\begin{array}{l}\text { B-type procyani- } \\
\text { din dimer }\end{array}$ & $\mathrm{C}_{30} \mathrm{H}_{26} \mathrm{O}_{12}$ & 578.1424 & 12.48 & 1 & \begin{tabular}{|l|} 
LC-QTOF- \\
MS \\
\end{tabular} & ESI \pm & MS/MS & 1.29 & 3.1 & 1.586 & 0.0011 \\
\hline $\begin{array}{l}\text { C-type procyani- } \\
\text { din trimer }\end{array}$ & $\mathrm{C}_{45} \mathrm{H}_{38} \mathrm{O}_{18}$ & 866.2058 & 10.9 & 4 & \begin{tabular}{|l} 
LC-QTOF- \\
MS \\
\end{tabular} & ESI- & Putative & 1.49 & 2.5 & 2.042 & 0.0031 \\
\hline $\begin{array}{l}\text { Butein -arabino- } \\
\text { syl-galactoside }\end{array}$ & $\mathrm{C}_{26} \mathrm{H}_{30} \mathrm{O}_{14}$ & 566.1636 & 1.12 & 9 & $\begin{array}{l}\text { LC-QTOF- } \\
\text { MS }\end{array}$ & ESI- & Putative & 1.75 & 0.3 & 1.318 & $4.91 \mathrm{E}-08$ \\
\hline $\begin{array}{l}\text { Caffeoylpelargo- } \\
\text { nidin 5-glucoside }\end{array}$ & $\mathrm{C}_{30} \mathrm{H}_{27} \mathrm{O}_{13}$ & 595.1452 & 12.09 & 2 & $\begin{array}{l}\text { LC-QTOF- } \\
\text { MS }\end{array}$ & ESI- & Putative & 1.41 & 0.8 & 1.146 & - \\
\hline Catechin & $\mathrm{C}_{15} \mathrm{H}_{14} \mathrm{O}_{6}$ & 290.079 & 11.39 & 2 & $\begin{array}{l}\text { LC-QTOF- } \\
\text { MS }\end{array}$ & ESI \pm & MS/MS & 2.03 & 12.5 & 2.733 & 0.00013 \\
\hline Epicatechin & $\mathrm{C}_{15} \mathrm{H}_{14} \mathrm{O}_{6}$ & 290.079 & 12.48 & 4 & $\begin{array}{l}\text { LC-QTOF- } \\
\text { MS } \\
\text { GC-QTOF- } \\
\text { MS }\end{array}$ & $\begin{array}{l}\text { ESI- } \\
\text { EI }\end{array}$ & $\begin{array}{l}\text { Putative } \\
\text { Identified }\end{array}$ & 1.76 & 3.1 & 1.110 & 0.00012 \\
\hline $\begin{array}{l}\text { Epicatechin } \\
\text { 3-glucoside }\end{array}$ & $\mathrm{C}_{21} \mathrm{H}_{24} \mathrm{O}_{11}$ & 452.1319 & 8.66 & 1 & \begin{tabular}{|l|} 
LC-QTOF- \\
MS \\
\end{tabular} & ESI- & Putative & 3.16 & 5.9 & 1.176 & 0.00029 \\
\hline $\begin{array}{l}\text { Epigallocatechin } \\
\text { 3-O-(4-hydroxy- } \\
\text { benzoate) }\end{array}$ & $\mathrm{C}_{22} \mathrm{H}_{18} \mathrm{O}_{9}$ & 426.0951 & 10.93 & 2 & $\begin{array}{l}\text { LC-QTOF- } \\
\text { MS }\end{array}$ & ESI- & Putative & 2.06 & 4.3 & 1.824 & 0.00081 \\
\hline $\begin{array}{l}\text { Isoflavonoid } \\
O \text {-glycosides }\end{array}$ & $\mathrm{C}_{28} \mathrm{H}_{34} \mathrm{O}_{12}$ & 562.205 & 11.26 & 4 & \begin{tabular}{|l|} 
LC-QTOF- \\
MS \\
\end{tabular} & ESI- & Putative & 1.03 & 7.2 & 1.460 & $9.10 \mathrm{E}-05$ \\
\hline $\begin{array}{l}\text { Kaempferol } \\
\text {-diacetyl-coumar- } \\
\text { ylrhamnoside }\end{array}$ & $\mathrm{C}_{34} \mathrm{H}_{30} \mathrm{O}_{14}$ & 662.1636 & 12.74 & 2 & $\begin{array}{l}\text { LC-QTOF- } \\
\text { MS }\end{array}$ & ESI- & Putative & 3.25 & 2.4 & 1.324 & 0.0017 \\
\hline $\begin{array}{l}\text { Kaempferol- } \\
\text { caffeoylglucosyl- } \\
\text { rhamnoside }\end{array}$ & $\mathrm{C}_{36} \mathrm{H}_{36} \mathrm{O}_{18}$ & 756.1902 & 12.59 & 1 & $\begin{array}{l}\text { LC-QTOF- } \\
\text { MS }\end{array}$ & ESI- & Putative & 2.33 & 2.2 & 1.329 & 0.0017 \\
\hline Viscumneoside V & $\mathrm{C}_{32} \mathrm{H}_{40} \mathrm{O}_{19}$ & 728.2164 & 1.11 & 6 & $\begin{array}{l}\text { LC-QTOF- } \\
\text { MS } \\
\end{array}$ & ESI- & Putative & 2.02 & 0.4 & 1.378 & $1.36 \mathrm{E}-08$ \\
\hline \multicolumn{12}{|c|}{ Purines and purine derivatives } \\
\hline $\begin{array}{l}\text { Hydroxyadenine } \\
\text { // Guanine }\end{array}$ & $\mathrm{C}_{5} \mathrm{H}_{5} \mathrm{~N}_{5} \mathrm{O}$ & 151.0494 & 1.96 & 3 & \begin{tabular}{|l|} 
LC-QTOF- \\
MS \\
\end{tabular} & ESI + & MS/MS & 1.08 & 3.1 & 3.264 & $7.22 \mathrm{E}-05$ \\
\hline Xanthine & $\mathrm{C}_{5} \mathrm{H}_{4} \mathrm{~N}_{4} \mathrm{O}_{2}$ & 152.0334 & 1.96 & 2 & $\begin{array}{l}\text { LC-QTOF- } \\
\text { MS }\end{array}$ & ESI + & Putative & 1.66 & 3.7 & 1.660 & $7.22 \mathrm{E}-05$ \\
\hline \multicolumn{12}{|c|}{ Organoheterocyclic compound } \\
\hline Continued & & & & & & & & & & & \\
\hline
\end{tabular}




\begin{tabular}{|c|c|c|c|c|c|c|c|c|c|c|c|}
\hline Compound name & $\begin{array}{l}\text { Molecular } \\
\text { Formula }\end{array}$ & $\begin{array}{l}\text { Molecular } \\
\text { weight (DB) } \\
\mathrm{g} / \mathrm{mol}\end{array}$ & RT (min) & $\begin{array}{l}\text { Mass error } \\
(\mathrm{ppm})\end{array}$ & $\begin{array}{l}\text { Analytical } \\
\text { platform }\end{array}$ & DET & CON & $\begin{array}{l}\mathrm{CV} \text { in } \mathrm{QC} \\
(\%)\end{array}$ & Fold Change & VIP Value & $\begin{array}{l}p \text {-value with } \\
\text { FDR }\end{array}$ \\
\hline Cytosine & $\mathrm{C}_{4} \mathrm{H}_{5} \mathrm{~N}_{3} \mathrm{O}$ & 111.0433 & 1.21 & 6 & $\begin{array}{l}\text { LC-QTOF- } \\
\text { MS }\end{array}$ & ESI+ & MS/MS & 1.74 & 3.9 & 2.042 & $2.00 \mathrm{E}-12$ \\
\hline Maltol & $\mathrm{C}_{6} \mathrm{H}_{6} \mathrm{O}_{3}$ & 126.0317 & 11.4 & 4 & $\begin{array}{l}\text { LC-QTOF- } \\
\text { MS }\end{array}$ & ESI- & Putative & 7.79 & 9.7 & 1.239 & 0.00015 \\
\hline \multicolumn{12}{|l|}{ Terpenoids } \\
\hline Cedrol & $\mathrm{C}_{15} \mathrm{H}_{26} \mathrm{O}$ & 222.1984 & 10.59 & 4 & $\begin{array}{l}\text { LC-QTOF- } \\
\text { MS }\end{array}$ & ESI+ & Putative & 1.83 & 7.7 & 1.941 & $7.22 \mathrm{E}-05$ \\
\hline Irone & $\mathrm{C}_{14} \mathrm{H}_{22} \mathrm{O}$ & 206.1671 & 10.69 & 5 & $\begin{array}{l}\text { LC-QTOF- } \\
\text { MS }\end{array}$ & ESI + & Putative & 1.58 & 35.7 & 3.768 & $7.22 \mathrm{E}-05$ \\
\hline Salannin & $\mathrm{C}_{34} \mathrm{H}_{44} \mathrm{O}_{9}$ & 596.2985 & 18.8 & 5 & $\begin{array}{l}\text { LC-QTOF- } \\
\text { MS }\end{array}$ & ESI- & Putative & 4.87 & 4.0 & 1.836 & $9.58 \mathrm{E}-05$ \\
\hline \multicolumn{12}{|l|}{ Glycosides } \\
\hline $\begin{array}{l}\text { Methylthiooctyl- } \\
\text { desulfoglucosi- } \\
\text { nolate }\end{array}$ & $\mathrm{C}_{16} \mathrm{H}_{31} \mathrm{NO}_{6} \mathrm{~S}_{2}$ & 397.1593 & 4.15 & 0 & $\begin{array}{l}\text { LC-QTOF- } \\
\text { MS }\end{array}$ & ESI- & Putative & 2.22 & 1.2 & 1.029 & 0.0082 \\
\hline \multicolumn{12}{|c|}{ Phenylpropanoids and polyketides } \\
\hline $\begin{array}{l}\text { Resveratrol } \\
\text { 3-sulfate }\end{array}$ & $\mathrm{C}_{14} \mathrm{H}_{12} \mathrm{O}_{6} \mathrm{~S}$ & 308.0355 & 11.94 & 0 & $\begin{array}{l}\text { LC-QTOF- } \\
\text { MS }\end{array}$ & ESI- & Putative & 1.34 & 5.1 & 1.150 & 0.00066 \\
\hline Oleandolide & $\mathrm{C}_{20} \mathrm{H}_{34} \mathrm{O}_{7}$ & 386.4798 & 4.22 & 5 & $\begin{array}{l}\text { LC-QTOF- } \\
\text { MS }\end{array}$ & ESI+ & Putative & 1.38 & 32.8 & 2.074 & $7.20 \mathrm{E}-05$ \\
\hline \multicolumn{12}{|l|}{ Fatty acyls } \\
\hline $\begin{array}{l}\text { Heptadecanoic } \\
\text { acid }\end{array}$ & $\mathrm{C}_{17} \mathrm{H}_{34} \mathrm{O}_{2}$ & 268.4348 & 19.81 & & $\begin{array}{l}\text { GC-QTOF- } \\
\text { MS }\end{array}$ & EI & Identified & 2.7 & 1.3 & - & 0.00022 \\
\hline $\begin{array}{l}\text { Hydroxyandros- } \\
\text { tane-3-glucuro- } \\
\text { nide }\end{array}$ & $\mathrm{C}_{25} \mathrm{H}_{40} \mathrm{O}_{9}$ & 484.2672 & 2.54 & 3 & $\begin{array}{l}\text { LC-QTOF- } \\
\text { MS }\end{array}$ & ESI \pm & Putative & 0.76 & 5.4 & 3.033 & $7.22 \mathrm{E}-05$ \\
\hline $\begin{array}{l}\text { hydroxy-tetrade- } \\
\text { cenoic acid }\end{array}$ & $\mathrm{C}_{14} \mathrm{H}_{26} \mathrm{O}_{3}$ & 242.1882 & 11.87 & 9 & $\begin{array}{l}\text { LC-QTOF- } \\
\text { MS }\end{array}$ & ESI- & Putative & 3.44 & 9.4 & 1.235 & $9.58 \mathrm{E}-05$ \\
\hline $\begin{array}{l}\text { Keto-decanoylcar- } \\
\text { nitine }\end{array}$ & $\mathrm{C}_{17} \mathrm{H}_{31} \mathrm{NO}_{5}$ & 329.2202 & 11.6 & 7 & $\begin{array}{l}\text { LC-QTOF- } \\
\text { MS }\end{array}$ & ESI- & Putative & 1.94 & 3.9 & 1.062 & 0.00021 \\
\hline $\begin{array}{l}\text { Linalool xylosyl- } \\
\text { glucoside }\end{array}$ & $\mathrm{C}_{21} \mathrm{H}_{36} \mathrm{O}_{10}$ & 448.2308 & 5.96 & 4 & $\begin{array}{l}\text { LC-QTOF- } \\
\text { MS }\end{array}$ & ESI \pm & Putative & 1.85 & 57.7 & 3.051 & $7.20 \mathrm{E}-05$ \\
\hline $\begin{array}{l}\text { Methylbutanoyl)- } \\
\text { 6-apiosylglucose }\end{array}$ & $\mathrm{C}_{16} \mathrm{H}_{28} \mathrm{O}_{11}$ & 396.1632 & 4.31 & 1 & $\begin{array}{l}\text { LC-QTOF- } \\
\text { MS }\end{array}$ & ESI- & Putative & 6.42 & 1.8 & 1.053 & 0.00049 \\
\hline Methylmalate & $\mathrm{C}_{5} \mathrm{H}_{8} \mathrm{O}_{5}$ & 148.0372 & 1.15 & 7 & $\begin{array}{l}\text { LC-QTOF- } \\
\text { MS }\end{array}$ & ESI- & Putative & 1.62 & 0.5 & 1.532 & 0.00015 \\
\hline Myristic acid & $\mathrm{C}_{14} \mathrm{H}_{28} \mathrm{O}_{2}$ & 228.3709 & 16.94 & - & $\begin{array}{l}\text { GC-QTOF- } \\
\text { MS }\end{array}$ & EI & Identified & 2.5 & 1.3 & - & 0.0051 \\
\hline Oleic acid & $\mathrm{C}_{18} \mathrm{H}_{34} \mathrm{O}_{2}$ & 282.4614 & 20.47 & - & $\begin{array}{l}\text { GC-QTOF- } \\
\text { MS }\end{array}$ & EI & Identified & 12.0 & 1.3 & 1.03152 & - \\
\hline Stearic acid & $\mathrm{C}_{18} \mathrm{H}_{36} \mathrm{O}_{2}$ & 284.4772 & 20.68 & - & $\begin{array}{l}\text { GC-QTOF- } \\
\text { MS }\end{array}$ & EI & Identified & 2.7 & 1.2 & 1.24361 & - \\
\hline \multicolumn{12}{|l|}{ Lipids } \\
\hline Deoxyestradiol & $\mathrm{C}_{18} \mathrm{H}_{24} \mathrm{O}$ & 256.1827 & 11.87 & 4 & $\begin{array}{l}\text { LC-QTOF- } \\
\text { MS }\end{array}$ & $\mathrm{ESI} \pm$ & Putative & 1.90 & 11.6 & 2.035 & $7.22 \mathrm{E}-05$ \\
\hline $\operatorname{LPC}(14: 0)$ & $\mathrm{C}_{22} \mathrm{H}_{44} \mathrm{NO}_{8} \mathrm{P}$ & 481.2805 & 13.35 & 4 & $\begin{array}{l}\text { LC-QTOF- } \\
\text { MS }\end{array}$ & ESI- & Putative & 1.05 & 17.3 & 1.689 & $9.10 \mathrm{E}-05$ \\
\hline LPC(18:2) & $\mathrm{C}_{26} \mathrm{H}_{50} \mathrm{NO}_{7} \mathrm{P}$ & 519.3325 & 19.92 & 1 & $\begin{array}{l}\text { LC-QTOF- } \\
\text { MS }\end{array}$ & ESI + & MS/MS & 5.83 & 5.6 & 3.004 & 0.00011 \\
\hline LPC(O-18:1) & $\mathrm{C}_{26} \mathrm{H}_{52} \mathrm{NO}_{7} \mathrm{P}$ & 521.3481 & 21.21 & 1 & $\begin{array}{l}\text { LC-QTOF- } \\
\text { MS }\end{array}$ & ESI+ & MS/MS & 5.20 & 4.2 & 2.800 & 0.00031 \\
\hline $\begin{array}{l}\text { Palmitoyl 3-car- } \\
\text { bacyclic Phospha- } \\
\text { tidic Acid }\end{array}$ & $\mathrm{C}_{20} \mathrm{H}_{39} \mathrm{O}_{5} \mathrm{P}$ & 390.2535 & 10.19 & 7 & $\begin{array}{l}\text { LC-QTOF- } \\
\text { MS }\end{array}$ & ESI + & Putative & 3.58 & 16.1 & 2.141 & $7.22 \mathrm{E}-05$ \\
\hline $\mathrm{PI}(18: 1)$ & $\mathrm{C}_{27} \mathrm{H}_{51} \mathrm{O}_{12} \mathrm{P}$ & 598.3118 & 20 & 2 & $\begin{array}{l}\text { LC-QTOF- } \\
\text { MS }\end{array}$ & ESI- & Putative & 16.18 & 2.0 & 1.061 & 0.0072 \\
\hline $\operatorname{PS}(21: 0)$ & $\mathrm{C}_{27} \mathrm{H}_{54} \mathrm{NO}_{9} \mathrm{P}$ & 567.3536 & 21.26 & 3 & $\begin{array}{l}\text { LC-QTOF- } \\
\text { MS }\end{array}$ & ESI- & Putative & 15.59 & 2.7 & 1.082 & 0.0012 \\
\hline Sphinganine & $\mathrm{C}_{18} \mathrm{H}_{39} \mathrm{NO}_{2}$ & 301.2981 & 18.83 & 2 & $\begin{array}{l}\text { LC-QTOF- } \\
\text { MS }\end{array}$ & ESI + & MS/MS & 3.08 & 0.6 & 1.653 & 0.00016 \\
\hline $\begin{array}{l}\text { Sulfoglycolitho- } \\
\text { cholate }\end{array}$ & $\mathrm{C}_{26} \mathrm{H}_{42} \mathrm{NO}_{7} \mathrm{~S}$ & 512.2682 & 6.05 & 5 & $\begin{array}{l}\text { LC-QTOF- } \\
\text { MS }\end{array}$ & ESI \pm & Putative & 1.85 & 35.0 & 2.272 & $7.22 \mathrm{E}-05$ \\
\hline
\end{tabular}

Table 1. Metabolites with statistical significance in the two phases of the fermentation process identified by metabolic fingerprinting using LC-QTOF-MS $( \pm)$ and GC-QTOF-MS $(+) .{ }^{a} \mathrm{DET}$ : detection mode; ${ }^{\mathrm{b}} \mathrm{CV}$, coefficient of variation of metabolites in QC samples; ${ }^{\mathrm{c}} \mathrm{VIP}$, Variable importance in projection; ${ }^{\mathrm{d}} \mathrm{CON}$ : Confirmation; ${ }^{\mathrm{e}} p$-value obtained after Benjamini-Hochberg correction test. LC Liquid Chromatography, QTOF-MS quadrupole time-of-flight mass spectrometry. 
linalool xylosyt-glucoside
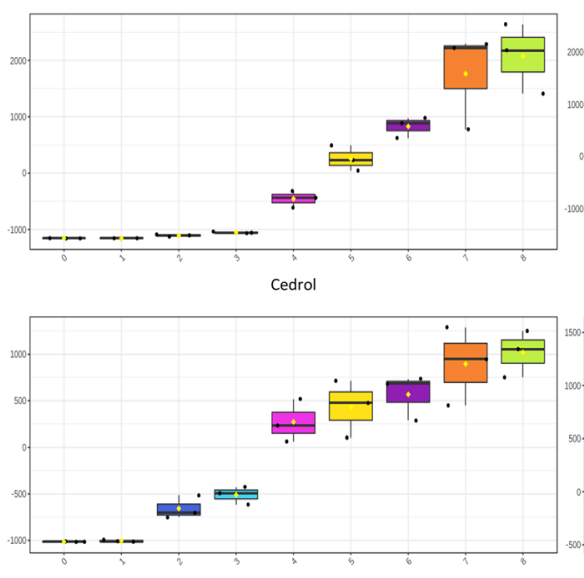

Methylcoumarin

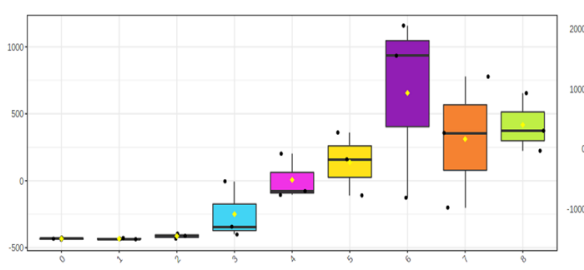

Irone

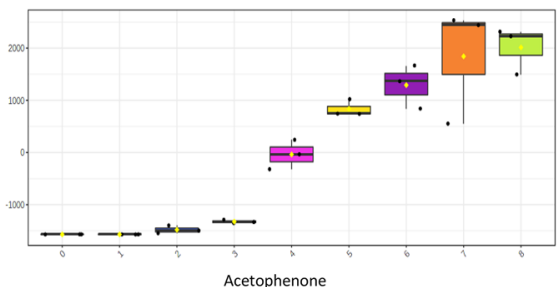

Acetophenone

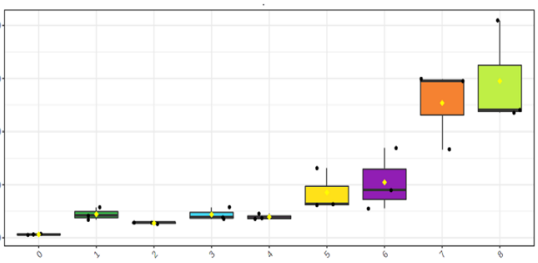

Vanillin

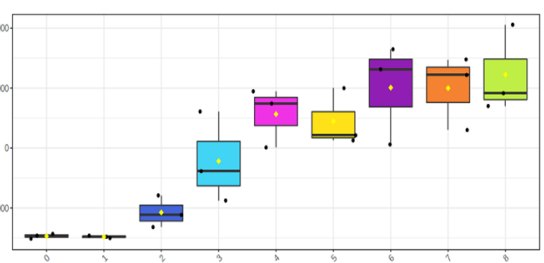

Coumarin
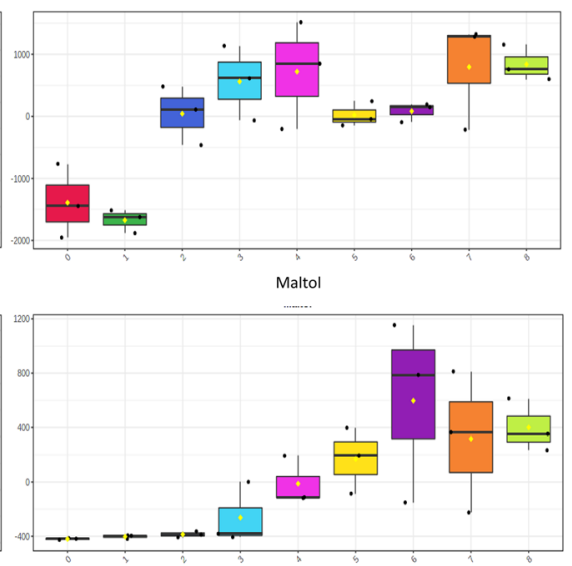

Vanillin isobutyrate

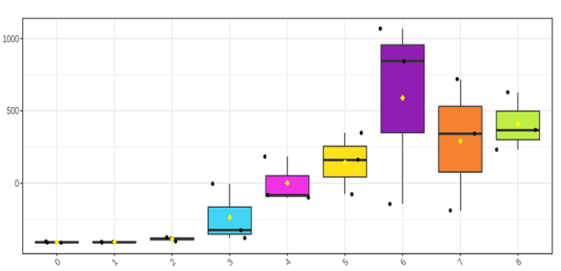

Figure 7. Box plots of metabolites linked with fine-flavor cocoa sensorial notes significantly differ throughout fermentation days (one-way ANOVA correcting for false discovery rate, FDR). Linalool xylosyl-glucoside (fruity, floral), irone (floral), coumaric acid (floral), cedrol (floral, woody,sweet), acetophenone (floral), maltol (caramel, fruity), methylcoumarin (fruity,floral), vanillin (vanilla, chocolate), and vanillin isobutyrate (caramel, chocolate, fruity).
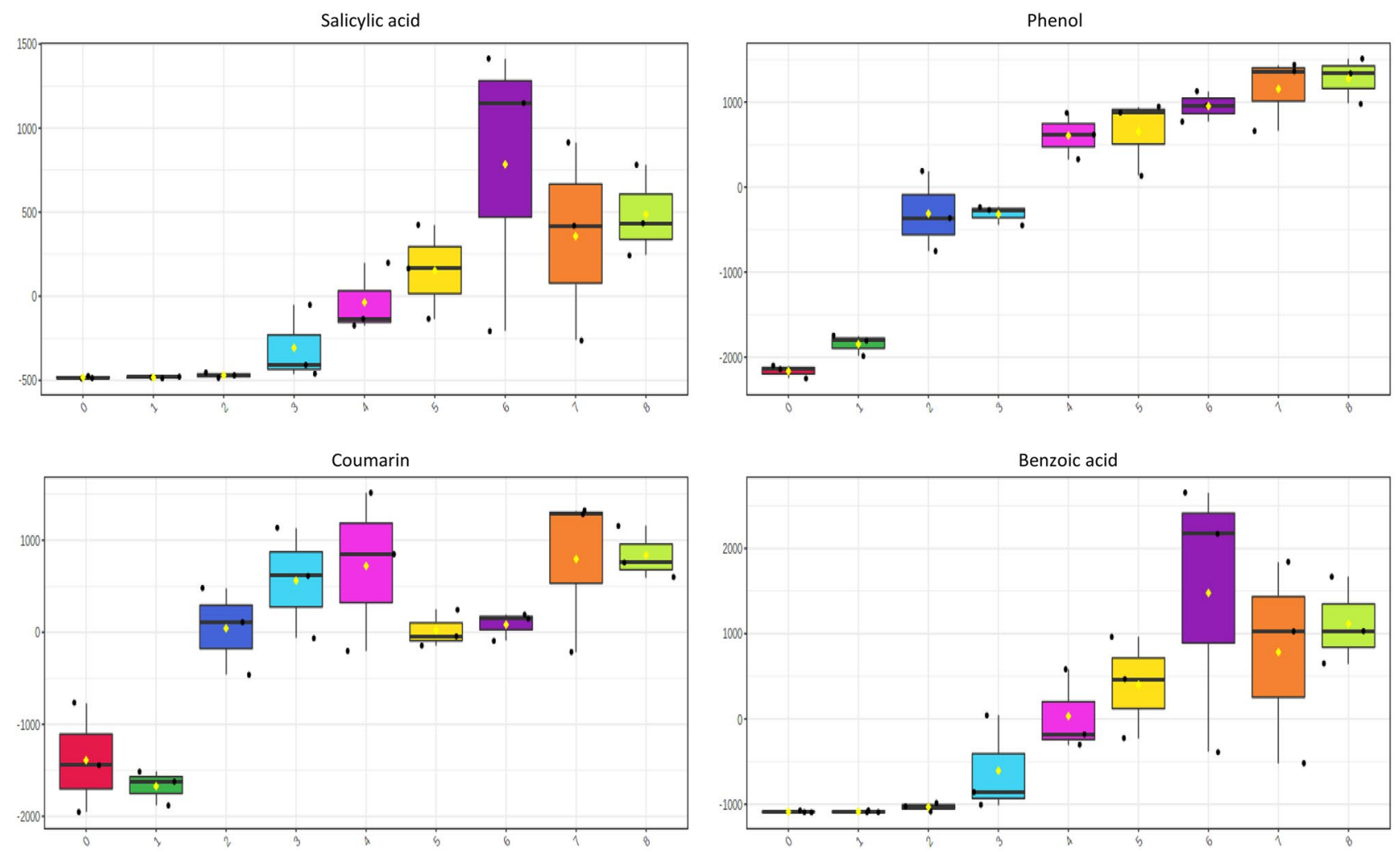

Figure 8. Box plots of metabolites linked with undesirable cocoa sensorial notes with significant differences throughout fermentation days (one-way ANOVA correcting for false discovery rate, FDR). Salicylic acid (phenolic, faint), phenol (phenolic), benzoic acid (urine, faint), coumarin (green, bitter). 
Catechin

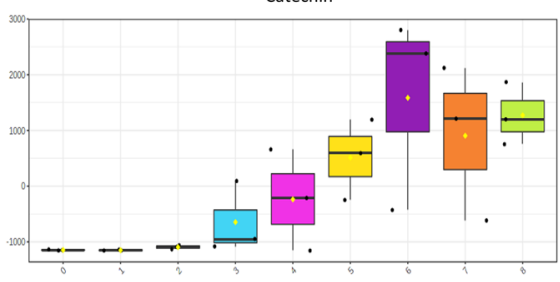

A-type procyanidin dimer

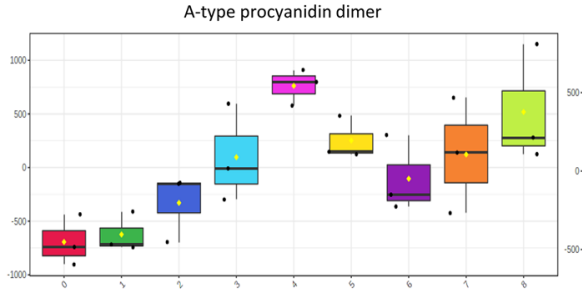

Epicatechin

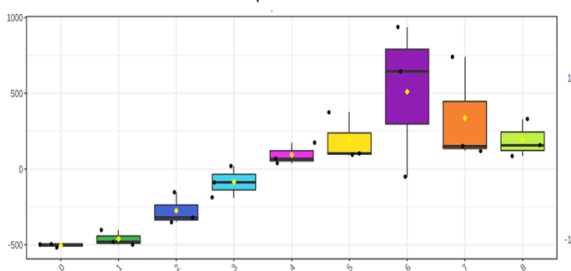

Isoflavonoid O-glycoside

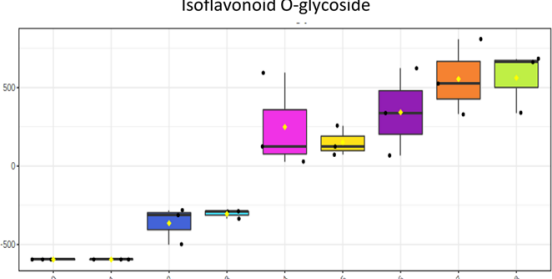

Aspartic acid

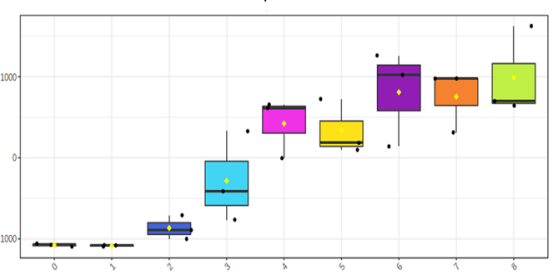

Dopamine

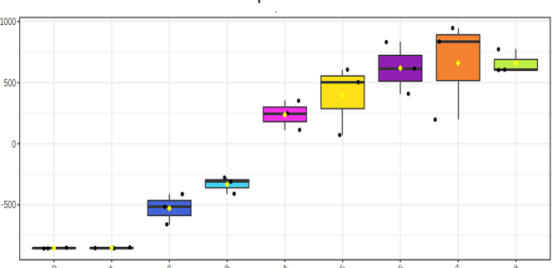

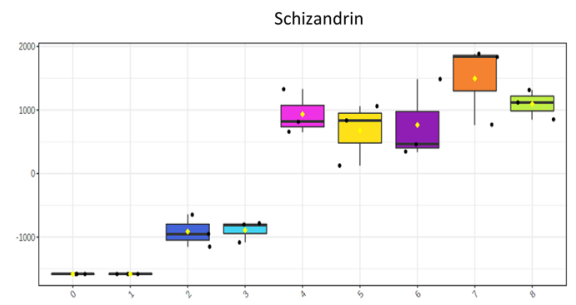

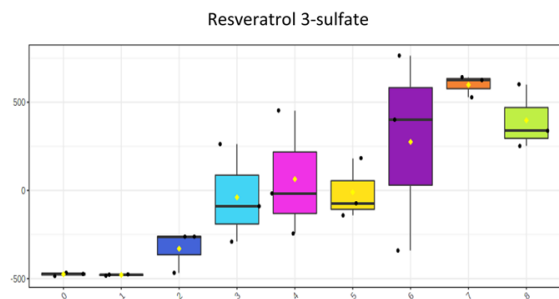

Figure 9. Box plots of bioactive metabolites with significant differences throughout fermentation days (oneway ANOVA correcting for false discovery rate, FDR).

from complex polyphenol degradation processes that can involve the action of weak acids and the temperature changes into the beans, oxidation reactions, and hydrolysis by polyphenol oxidases ${ }^{62,63}$ or in the secondary metabolism of some microorganisms ${ }^{64}$, but the biochemical mechanisms behind their production remain unclear.

Several studies associate non-conventional microorganisms' groups with the production of flavor molecules ${ }^{64-67}$. For instance, unconventional strains of Saccharomyces, Candida, Pseudomonas, and Bacillus species, widely reported in cocoa fermentations worldwide, can also produce vanillin and derivates from feluric $\operatorname{acid}^{65,66}$. Different fungi species produce coumarin and derivates naturally ${ }^{64,67}$. However, to fully connect the metabolite production with the microbiome of cocoa fermentation, an integration of metabolomics and metagenomic data is required, and it will be the focus of future research.

\section{Conclusions}

Our work reveals a clear connection between cocoa mass temperature and the metabolic activity during the fermentation of fine-flavor cocoa. Using temperature dynamic as a relevant parameter during cocoa fermentation, we proposed a new cocoa fermentation metabolic paradigm that offers a complete insight into how temperature regulates biochemical reactions during cocoa fermentation, considering global metabolic activity. This shift is a crucial step to develop strategies based on temperature control to drive cocoa fermentations toward better quality chocolate. Nevertheless, further research is required to further dissect the link between microorganisms and metabolites. This is a crucial step in order to understand the impact in the sensorial profile of a significant number of cocoa compounds.

We also elucidated metabolic modifications throughout fermentation associated with proteolysis and secondary metabolism. Our results reveal a potential for bioprospection beyond chocolate production of some peptides and polyphenols with attractive bioactive properties that arise during cocoa fermentation-considering that a significant proportion of these molecules are lost in post-fermentation processes. However, the bioactive properties of most of these identified metabolites also still need to be entirely dissected.

\section{Data availability}

All data generated or analyzed during this study are included in this published article (and its Supplementary Information files).

Received: 12 August 2021; Accepted: 14 October 2021

Published online: 09 November 2021

\section{References}

1. Ordoñez-Araque, R. H., Landines-Vera, E. F., Urresto-Villegas, J. C. \& Caicedo-Jaramillo, C. F. Microorganisms during cocoa fermentation: Systematic review. Foods Raw Mater. 8, 155-162 (2020). 
2. Castro-Alayo, E. M., Idrogo-Vásquez, G., Siche, R. \& Cardenas-Toro, F. P. Formation of aromatic compounds precursors during fermentation of Criollo and Forastero cocoa. Heliyon 5, e01157 (2019).

3. Schwan, R. F. \& Wheals, A. E. The microbiology of cocoa fermentation and its role in chocolate quality. Crit. Rev. Food Sci. Nutr. 44, 205-221 (2004).

4. Tran, P. D. et al. Assessing cocoa aroma quality by multiple analytical approaches. Food Res. Int. 77, 657-669 (2015).

5. Aprotosoaie, A. C., Luca, S. V. \& Miron, A. Flavor chemistry of cocoa and cocoa products-an overview. Compr. Rev. Food Sci. Food Saf. 15, 73-91 (2016).

6. Afoakwa, E. O. Encyclopedia of Biotechnology in Agriculture and Food. in Kirk-Othmer Encyclopedia of Chemical Technology (John Wiley \& Sons, Inc., 2012). doi:https://doi.org/10.1002/0471238961.chocafoa.a01.

7. Guzmán-Alvarez, R. E. \& Márquez-Ramos, J. G. Fermentation of Cocoa Beans. Ferment. - Process. Benefits Risks [Working Title] (2021) doi:https://doi.org/10.5772/INTECHOPEN.98756.

8. Lima, Lí. \& J. R., Almeida, M. H., Rob Nout, M. J. \& Zwietering, M. H.,. Theobroma cacao L, 'the food of the gods': Quality determinants of commercial cocoa beans, with particular reference to the impact of fermentation. Crit. Rev. Food Sci. Nutr. 51, 731-761 (2011).

9. De Vuyst, L. \& Weckx, S. The cocoa bean fermentation process: from ecosystem analysis to starter culture development. J. Appl. Microbiol. 121, 5-17 (2016).

10. John, W. A. et al. Experimentally modelling cocoa bean fermentation reveals key factors and their influences. Food Chem. 302, $125335(2020)$

11. Moreno-Zambrano, M., Grimbs, S., Ullrich, M. S. \& Hütt, M. T. A mathematical model of cocoa bean fermentation. R. Soc. Open Sci. 5, 180964 (2018).

12. Kresnowati, M. T. A. P., Gunawan, A. Y. \& Muliyadini, W. Kinetics model development of cocoa bean fermentation. in AIP Conference Proceedings vol. 1699030004 (American Institute of Physics Inc., 2015).

13. Fernández-Niño, M. et al. Dissecting industrial fermentations of fine flavour cocoa through metagenomic analysis. Sci. Rep. 11, $1-14(2021)$.

14. Serra, J. L. et al. Determination of the microbial community in Amazonian cocoa bean fermentation by Illumina-based metagenomic sequencing. Lwt 106, 229-239 (2019).

15. De Vuyst, L. \& Leroy, F. Functional role of yeasts, lactic acid bacteria and acetic acid bacteria in cocoa fermentation processes. FEMS Microbiol. Rev. 44, 432-453 (2020).

16. De Vuyst, L., Lefeber, T., Papalexandratou, Z. \& Camu, N. The Functional Role of Lactic Acid Bacteria in Cocoa Bean Fermentation. in Biotechnology of Lactic Acid Bacteria 301-325 (Wiley-Blackwell, 2010). doi:https://doi.org/10.1002/9780813820866.ch17.

17. Morelli, L. et al. Genome-scale metabolic reconstruction of acetobacter pasteurianus 386B, a candidate functional starter culture for cocoa bean fermentation. Front. Microbiol. 10, 10 (2019).

18. Adler, P., Bolten, C. J., Dohnt, K., Hansen, C. E. \& Wittmann, C. Core fluxome and metafluxome of lactic acid bacteria under simulated cocoa pulp fermentation conditions. Appl. Environ. Microbiol. 79, 5670-5681 (2013).

19. Adler, P. et al. The key to acetate: Metabolic fluxes of acetic acid bacteria under cocoa pulp fermentation-simulating conditions. Appl. Environ. Microbiol. 80, 4702-4716 (2014).

20. Sarbu, I. \& Csutak, O. The microbiology of cocoa fermentation. in Caffeinated and Cocoa Based Beverages: Volume 8. The Science of Beverages 423-446 (Elsevier Inc., 2019). doi:https://doi.org/10.1016/B978-0-12-815864-7.00013-1.

21. Romanens, E. et al. A lab-scale model system for cocoa bean fermentation. Appl. Microbiol. Biotechnol. 102, 3349-3362 (2018).

22. Verce, M. et al. A combined metagenomics and metatranscriptomics approach to unravel costa rican cocoa box fermentation processes reveals yet unreported microbial species and functionalities. Front. Microbiol. 102, 245 (2021).

23. Almeida, O. G. G. \& De Martinis, E. C. P. Metagenome-assembled genomes contribute to unraveling of the microbiome of cocoa fermentation. Appl. Environ. Microbiol. 87, e0058421 (2021).

24. Mayorga-Gross, A. L., Quirós-Guerrero, L. M., Fourny, G. \& Vaillant, F. An untargeted metabolomic assessment of cocoa beans during fermentation. Food Res. Int. 89, 901-909 (2016).

25. Kuhnert, N., D’souza, R. N., Behrends, B., Ullrich, M. S. \& Witt, M. Investigating time dependent cocoa bean fermentation by ESI-FT-ICR mass spectrometry. Food Res. Int. 133, 109209 (2020).

26. Devy, L., Susilo, A. W., Wachjar, A. \& Sobir.,. Metabolite profiling of Indonesian cacao using Gas Chromatography-Mass Spectrometry. IOP Conf. Ser. Earth Environ. Sci. 347, 012071 (2019).

27. Tuenter, E. et al. Non-volatile and volatile composition of West African bulk and Ecuadorian fine-flavor cocoa liquor and chocolate. Food Res. Int. 130, 108943 (2020).

28. Santander, M., Vaillant, F., Sinuco, D., Rodríguez, J. \& Escobar, S. Enhancement of fine flavour cocoa attributes under a controlled postharvest process. Food Res. Int. 143, 110236 (2021).

29. Kealey, K., Snyder, R. \& Romanczyck, L. Patent Application Publication ( 10 ) Pub . No .: US 2007 / 0197807 A1. Us 2007 / 0197807 al vol. 1 19-21 (2007).

30. Cala, M. P. et al. Multiplatform plasma metabolic and lipid fingerprinting of breast cancer: A pilot control-case study in Colombian Hispanic women. PLoS ONE 13, e0190958 (2018).

31. Gil-De-La-Fuente, A. et al. CEU Mass Mediator 3.0: A Metabolite Annotation Tool. J. Proteome Res. 18, 797-802 (2019).

32. Illeghems, K., Weckx, S. \& De Vuyst, L. Applying meta-pathway analyses through metagenomics to identify the functional properties of the major bacterial communities of a single spontaneous cocoa bean fermentation process sample. Food Microbiol. 50, 54-63 (2015).

33. Hamdouche, Y. et al. Impact of turning, pod storage and fermentation time on microbial ecology and volatile composition of cocoa beans. Food Res. Int. 119, 477-491 (2019).

34. Sarbu, I. \& Csutak, O. The microbiology of cocoa fermentation. in Caffeinated and Cocoa Based Beverages: Volume 8. The Science of Beverages 423-446 (2019). doi:https://doi.org/10.1016/B978-0-12-815864-7.00013-1.

35. Nielsen, D., Crafack, M., Jespersen, L. \& Jakobsen, M. The Microbiology of Cocoa Fermentation. in Chocolate in Health and Nutrition 39-60 (2013). doi:https://doi.org/10.1007/978-1-61779-803-0.

36. de Melo Pereira, G. V., Magalhães, K. T., de Almeida, E. G., da Silva Coelho, I. \& Schwan, R. F. Spontaneous cocoa bean fermentation carried out in a novel-design stainless steel tank: Influence on the dynamics of microbial populations and physical-chemical properties. Int. J. Food Microbiol. 161, 121-133 (2013).

37. Hatmi, R. U., Kobarsih, M. \& Cahyaningrum, N. Fungi Level Analysis of Cocoa Beans Based on Fermentation Box Type and Duration. Procedia Food Sci. 3, 371-382 (2015).

38. Fang, Y. et al. Chemical and flavor profile changes of cocoa beans (Theobroma cacao L) during primary fermentation. Food Sci. Nutr. 8, 4121-4133 (2020).

39. da Moreira, I. M. \& V., Miguel, M. G. da C. P., Duarte, W. F., Dias, D. R. \& Schwan, R. F.,. Microbial succession and the dynamics of metabolites and sugars during the fermentation of three different cocoa (Theobroma cacao L) hybrids. Food Res. Int. 54, 9-17 (2013).

40. Agyirifo, D. S. et al. Metagenomics analysis of cocoa bean fermentation microbiome identifying species diversity and putative functional capabilities. Heliyon 5, e02170 (2019).

41. Caspeta, L. \& Nielsen, J. Thermotolerant yeast strains adapted by laboratory evolution show trade-off at ancestral temperatures and preadaptation to other stresses. MBio 6, 4 (2015). 
42. Adamberg, K., Kask, S., Laht, T. M. \& Paalme, T. The effect of temperature and pH on the growth of lactic acid bacteria: a pHauxostat study. Int. J. Food Microbiol. 85, 171-183 (2003).

43. Moens, F., Lefeber, T. \& De Vuyst, L. Oxidation of metabolites highlights the microbial interactions and role of Acetobacter pasteurianus during cocoa bean fermentation. Appl. Environ. Microbiol. 80, 1848-1857 (2014).

44. Kadow, D., Niemenak, N., Rohn, S. \& Lieberei, R. Fermentation-like incubation of cocoa seeds (Theobroma cacao L) - Reconstruction and guidance of the fermentation process. LWT - Food Sci. Technol. 62, 357-361 (2015).

45. Pacheco-Montealegre, M. E., Dávila-Mora, L. L., Botero-Rute, L. M., Reyes, A. \& Caro-Quintero, A. Fine resolution analysis of microbial communities provides insights into the variability of cocoa bean fermentation. Front. Microbiol. 11, 1-15 (2020).

46. Scollo, E. et al. Proteomic and peptidomic UHPLC-ESI MS/MS analysis of cocoa beans fermented using the Styrofoam-box method. Food Chem. 316, 126350 (2020).

47. John, W. A. et al. Aseptic artificial fermentation of cocoa beans can be fashioned to replicate the peptide profile of commercial cocoa bean fermentations. Food Res. Int. 89, 764-772 (2016).

48. Scalone, G. L. L. et al. Cocoa-specific flavor components and their peptide precursors. Food Res. Int. 123, 503-515 (2019).

49. D'Souza, R. N. et al. Degradation of cocoa proteins into oligopeptides during spontaneous fermentation of cocoa beans. Food Res. Int. 109, 506-516 (2018).

50. Kiyat, W. E., Monica, A., Qomariyah, N. \& Manurung, B. S. Enzymes Involving in Chocolate Processing. J. Food Pharm. Sci. 6, $1-6(2018)$.

51. Sousa, L. S., de Rocha, F. \& S., Silveira, P. T. de S., Bispo, E. da S. \& Soares, S. E.,. Enzymatic activity of proteases and its isoenzymes in fermentation process in cultivars of cocoa (Theobroma cacao L) produced in southern Bahia. Brazil. Food Sci. Technol. 36, 656-663 (2016).

52. Domínguez-Pérez, L. A., Beltrán-Barrientos, L. M., González-Córdova, A. F., Hernández-Mendoza, A. \& Vallejo-Cordoba, B. Artisanal cocoa bean fermentation: From cocoa bean proteins to bioactive peptides with potential health benefits. J. Funct. Foods 73, $104134(2020)$.

53. Garg, N. et al. FlavorDB: A database of flavor molecules. Nucleic Acids Res. 46, 1210-1216 (2018).

54. De Taeye, C., Eyamo Evina, V., Caullet, G., Niemenak, N. \& Collin, S. Fate of anthocyanins through cocoa fermentation emergence of new polyphenolic dimers. J. Agric. Food Chem. 64, 8876-8885 (2016).

55. Racine, K. C. et al. Development and characterization of a pilot-scale model cocoa fermentation system suitable for studying the impact of fermentation on putative bioactive compounds and bioactivity of cocoa. Foods 8, 102 (2019).

56. Abhay, S. M., Hii, C. L., Law, C. L., Suzannah, S. \& Djaeni, M. Effect of hot-air drying temperature on the polyphenol content and the sensory properties of cocoa beans. Int. Food Res. J. 23, 1479-1484 (2016).

57. Pavlović, A. N. et al. Effect of storage temperature on the decay of catechins and procyanidins in dark chocolate. Czech J. Food Sci. 35, 360-366 (2017).

58. Papalexandratou, Z. et al. Linking cocoa varietals and microbial diversity of Nicaraguan fine cocoa bean fermentations and their impact on final cocoa quality appreciation. Int. J. Food Microbiol. 304, 106-118 (2019).

59. Zugravu, C. \& Otelea, M. R. Dark chocolate: To eat or not to eat? A review. J. AOAC Int. 102, 1388-1396 (2019).

60. Martens, C. R. et al. Chronic nicotinamide riboside supplementation is well-tolerated and elevates NAD + in healthy middle-aged and older adults. Nat. Commun. 9, 1-11 (2018).

61. Roshanzamir, F. \& Safavi, S. M. The putative effects of D-Aspartic acid on blood testosterone levels: A systematic review. Int. J. Reprod. Biomed. 15, 1 (2017).

62. Albertini, B. et al. Effect of fermentation and drying on cocoa polyphenols. J. Agric. Food Chem. 63, 9948-9953 (2015).

63. Kyi, T. M. et al. The kinetics of polyphenol degradation during the drying of Malaysian cocoa beans. Int. J. Food Sci. Technol. 40, 323-331 (2005).

64. Tm, C., Lbb, T. \& D, de O.,. Fungi as a source of natural coumarins production. Appl. Microbiol. Biotechnol. 100, 6571-6584 (2016).

65. Chen, P. et al. A microbial transformation using Bacillus subtilis B7-S to produce natural vanillin from ferulic acid. Sci. Rep. 6, $1-10$ (2016).

66. Cortez, D. V. \& Roberto, I. C. Individual and interaction effects of vanillin and syringaldehyde on the xylitol formation by Candida guilliermondii. Bioresour. Technol. 101, 1858-1865 (2010).

67. Jainara Santos, N. et al. Mapping the Biotransformation of Coumarins through Filamentous Fungi. Molecules 24, 3531 (2019).

68. Pang, Z. et al. MetaboAnalyst 5.0: Narrowing the gap between raw spectra and functional insights. Nucleic Acids Res. 49, W388W396 (2021).

\section{Acknowledgements}

We thank the Grupo de Diseño de Productos y Procesos (GDPP) researchers for their constant contributions, correct observations, and excellent knowledge. The authors acknowledge the instruments and scientific and technical assistance of Metabolomics Core Facility - MetCore at the Universidad de Los Andes, a facility supported by the vice-presidency for research. We thank the ministry of environment and sustainable development for permission to access genetic and derivate resources according to resolution No 284 of 2020.

\section{Author contributions}

Conceptualization: M.F.N., M.C., M.J.C., and A.G.B. Data curation: F.H.R., M.C., and M.F.N. Formal analysis: F.H.R., M.C., and M.F.N. Funding acquisition: M.F.N., M.C., M.J.C., and A.G.B. Investigation: F.H.R., M.C., M.F.N., M.J.C., J.L.A., H.H.O., and A.G.B. Methodology: F.H.R., M.C., M.F.N., M.J.C., J.L.A., C.M.R., H.H.O., and A.G.B. Project administration: M.C., M.F.N., M.J.C., H.H.O., and A.G.B. Supervision \& Validation: M.C., M.F.N., and A.G.B. Visualization: F.H.R., M.C., and M.F.N. Writing \pm original draft: F.H.R., M.C., M.F.N., M.J.C., J.L.A., C.M.R., H.H.O., and A.G.B. Writing \pm review \& editing: F.H.R., M.C., M.F.N., M.J.C., J.L.A., C.M.R., H.H.O., and A.G.B. All authors have approved the final version.

\section{Competing interests}

The authors declare no competing interests.

\section{Additional information}

Supplementary Information The online version contains supplementary material available at https://doi.org/ 10.1038/s41598-021-01427-8.

Correspondence and requests for materials should be addressed to M.F.-N. or A.F.G.B.

Reprints and permissions information is available at www.nature.com/reprints. 
Publisher's note Springer Nature remains neutral with regard to jurisdictional claims in published maps and institutional affiliations.

(c) (i) Open Access This article is licensed under a Creative Commons Attribution 4.0 International License, which permits use, sharing, adaptation, distribution and reproduction in any medium or format, as long as you give appropriate credit to the original author(s) and the source, provide a link to the Creative Commons licence, and indicate if changes were made. The images or other third party material in this article are included in the article's Creative Commons licence, unless indicated otherwise in a credit line to the material. If material is not included in the article's Creative Commons licence and your intended use is not permitted by statutory regulation or exceeds the permitted use, you will need to obtain permission directly from the copyright holder. To view a copy of this licence, visit http://creativecommons.org/licenses/by/4.0/.

(C) The Author(s) 2021 